\title{
Recent Strategies for the Development of Biosourced-Monomers, Oligomers and Polymers-Based Materials: A Review with an Innovation and a Bigger Data Focus
}

\author{
Serge Rebouillat ${ }^{1}$, Fernand Pla ${ }^{2}$ \\ ${ }^{1}$ Currently with DuPont Int. Op. European Headquarters, Geneva, Switzerland \\ ${ }^{2}$ Laboratoire Réactions et Génie des Procédés, UMR 7274, CNRS-Université de Lorraine, Nancy, France \\ Email: sergereb@yahoo.com
}

How to cite this paper: Rebouillat, S. and Pla, F. (2016) Recent Strategies for the Development of Biosourced-Monomers, Oligomers and Polymers-Based Materials: $\mathrm{A}$ Review with an Innovation and a Bigger Data Focus. Journal of Biomaterials and Nanobiotechnology, 7, 167-213. http://dx.doi.org/10.4236/jbnb.2016.74017

Received: August 30, 2016

Accepted: October 18, 2016

Published: October 21, 2016

Copyright $\odot 2016$ by authors and Scientific Research Publishing Inc. This work is licensed under the Creative Commons Attribution International License (CC BY 4.0).

http://creativecommons.org/licenses/by/4.0/

\begin{abstract}
After setting the ground of the quantum innovation potential of biosourced entities and outlining the inventive spectrum of adjacent technologies that can derive from those, the current review highlights, with the support of Bigger Data approaches, and a fairly large number of articles, more than 250 and 10,000 patents, the following. It covers an overview of biosourced chemicals and materials, mainly biomonomers, biooligomers and biopolymers; these are produced today in a way that allows reducing the fossil resources depletion and dependency, and obtaining environmentallyfriendlier goods in a leaner energy consuming society. A process with a realistic productivity is underlined thanks to the implementation of recent and specifically effective processes where engineered microorganisms are capable to convert natural non-fossil goods, at industrial scale, into fuels and useful high-value chemicals in good yield. Those processes, further detailed, integrate: metabolic engineering involving 1) system biology, 2) synthetic biology and 3) evolutionary engineering. They enable acceptable production yield and productivity, meet the targeted chemical profiles, minimize the consumption of inputs, reduce the production of by-products and further diminish the overall operation costs. As generally admitted the properties of most natural occurring biopolymers (e.g., starch, poly (lactic acid), PHAs.) are often inferior to those of the polymers derived from petroleum; blends and composites, exhibiting improved properties, are now successfully produced. Specific attention is paid to these aspects. Then further evidence is provided to support the important potential and role of products deriving from the biomass in general. The need to en-
\end{abstract}


ter into the era of Bigger Data, to grow and increase the awareness and multidimensional role and opportunity of biosourcing serves as a conclusion and future prospects. Although providing a large reference database, this review is largely initiatory, therefore not mimicking previous classic reviews but putting them in a multiplying synergistic prospective.

\section{Keywords}

Biomass, Biosourced Monomers, Advanced Biomaterials, Chemical Building Blocks, Design Strategy, Metabolic Engineering, Innovation, Bigger Data

\section{Introduction}

\subsection{A Contextual Innovation \& Bigger Data Emphasis}

Innovation associated with the main topic of this review has attracted an increasing number of players over the last 20 years and more noticeably recently. The "Bigger Data" fervor has added a momentum to the bioscience application to industrial transformation of "green" chemistry in general.

As an example, the world Intellectual Property Organization (WIPO) published a study on microalgae-related technologies [1]. The importance of patent activity is of central value in this report.

Bigger data and, Innovation and IP, reviews applicable to green and biosourced technologies have also diversely been covered by S. Rebouillat et al. [2]-[4] and illustrated in more practical cases associated to high performance materials [5], high performance bioengineered fluids [6]-[8], nanostructured materials [9], protein valorization [10].

Reviews are very valuable pieces of work providing the necessary orientations and stimulating combinatorial innovation from an open mindset. With the advent of bigger data, one would easily relegate reviews to "historic" exercises given the accessibility of data and Bigger Data. The authors have contributed to underlining the attention that must be paid to larger set of data in terms of interpretation risks and opportunity. The field of interest, i.e. "Biosourced", is by far a tremendous topic with regards to Bigger Data and is worth some comparative educational, largely introductive and initiating, analysis. We hereafter propose a few graphical representations in the context of innovation and Bigger Data in Figures 1-4.

At a glance, Figure 1 provides the numbers of current innovation styles, from open to close, disruptive, collaboratory ${ }^{\oplus}$, from reverse to inclusive, nested and frugal. Those terminologies are more or less self-explanatory. Rebouillat et al. wrote a review on the matter [11], covering some of them. On the same figure, the "Not Invented Here", NHI, is illustrated, to that effect it is worth mentioning that the Bigger Data approach tends to naturally challenge that old NIH orthodoxy still largely encountered in large organizations. The creative reverse cycling shower picture tends to illustrate how essential the 


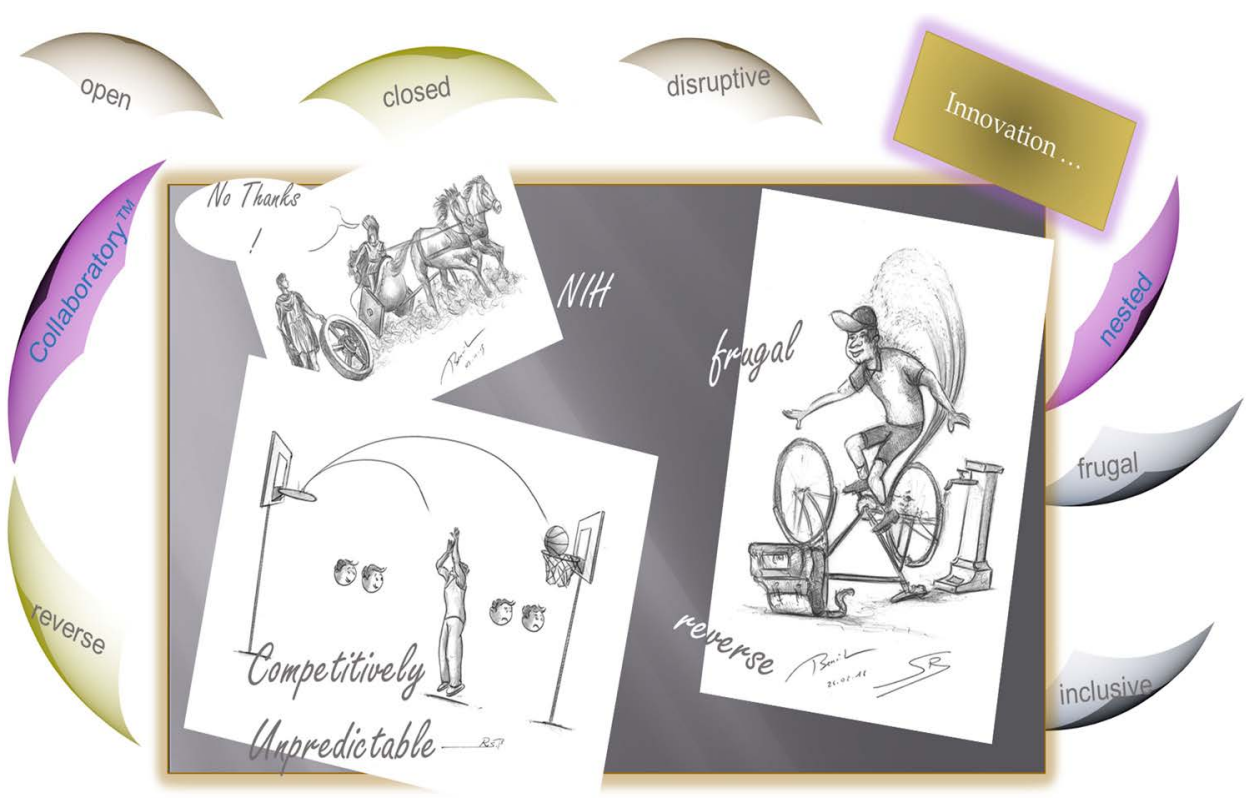

Figure 1. The innovation illustrated styles and usual categories.

last mile and the reachability of the target in a creative fashion are. Frugal concepts unable adaptation and use of local means allow the "same" performance as so called top of the line, rocket science or trendy, offerings. Biosourcing has a role to play with regard to that frugal orientation, definitely happening in line with inclusive approaches. The last picture of Figure 1 attracts the attention to the need for innovation to be inherently and as an oxymoron "Competitively Unpredictable". Let's leave room to the reader for his/her own interpretation. Some famous products such as breathable selective membranes constitute examples especially in the way they became commercial. Additionally, biomimicry brain storming [3] often reveals paradoxes such as those illustrated on that drawing.

Search methods raise another challenge associated with Bigger Data. The WIPO review [1] underlines some aspects of it. The "used in the art" search methods in the context of Intellectual Property (IP) and Bigger Data have been reviewed by Rebouillat et al. [12]. This current review, "Biosourced", the WIPO's patent landscape report on microalgae-related technologies [1], representing a biosourcing potential that should not be ignored and the review [12] are connected in this introduction to alert on the risks and opportunities in the Bigger Data arena.

There are a good number of specialized algorithms and associated platforms capable of performing analytics on large patent data banks-covering the 90 million patents from around the world-available from different patent offices (EPO, WIPO, USPTO, KIPO...), about 12 main commercial or publically available platforms. The platform used by WIPO [1] is called $\mathrm{W}$ in our review to remain balanced and neutral in the naming of commercial products.

For educational and comparative purpose, we have used two other platforms called $\mathrm{Q}$ and $\mathrm{G}$, both provide similar analysis compared to $\mathrm{W}$. 
Figure 2, Figure 3 and Figure 4 provide three analytics and metrics using the 3 platforms side by side, i.e. the patent activity over 20 years, the concept clustering and the assignees, companies or institutions, ranking.

The input selected to perform the analytics is the patent landscape keyword list provided in the WIPO report [1] on pages 63 and 64; list which comprises about 250 keywords related to, or adjacent to, the report subject matter which encompasses "Biosourced".

LSA, Latent Vectorial Semantic Analyses,

https://en.wikipedia.org/wiki/Latent_semantic_analysis, are specific algorithmic data treatments protected by each platform, from which are extracted the dominant concepts provided in Figure 3.

Figure 2 shows from the 3 analyses, approaches W [1], Q, G, performed on an average of about 10,000 (respectively $11 \mathrm{k}, 10 \mathrm{k}$ and $7 \mathrm{k}$ ) patent documents, an exponential increase in the patent activity and a concurring number of documents across the three analyses, respectively 830 patents documents in 2009 with platform W vs. 760 with Q and 740 with G. This is expected to be the case knowing that this relies on counts and database access which are publically reachable. Although this results in the analysis of 90 million patent documents, there is coherence among platforms with a Bigger Data analysis approach.

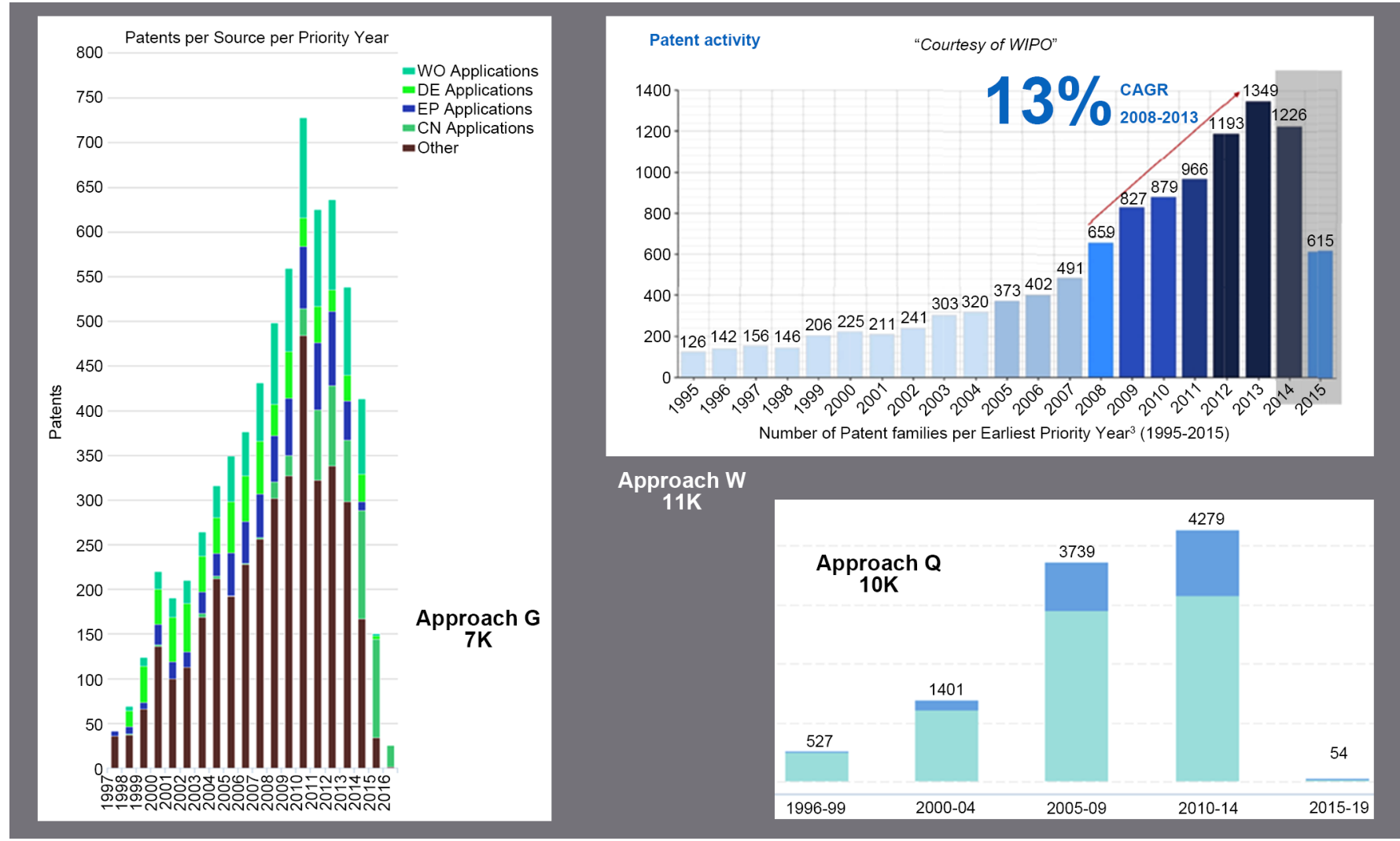

Figure 2. The IP activity in the fields of Interest over a span of 20 years (1995-2015) processed with 3 algorithmic analytical approaches (W, Q, G). 


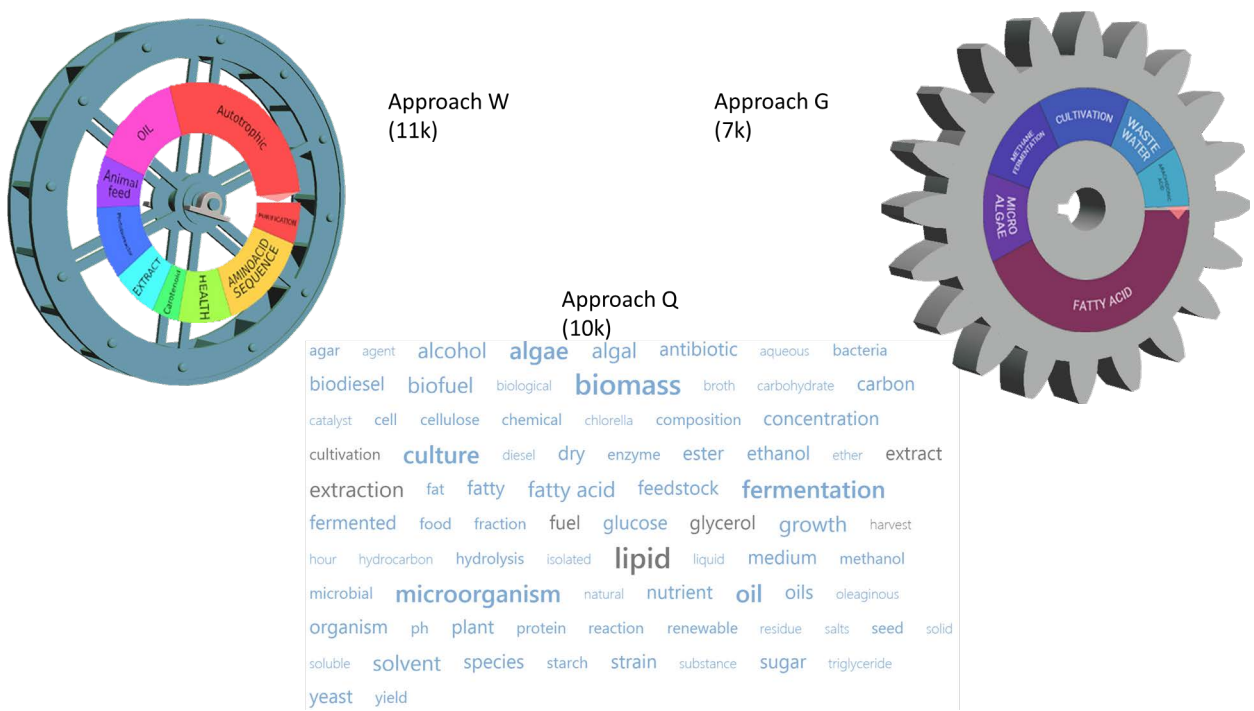

Figure 3. Concepts clustering from keyword list of [1] via LSA as per the 3 algorithmic analysis IP platforms (W, Q, G).

\begin{tabular}{|c|c|c|}
\hline Approach W & Approach G & Approach Q \\
\hline BASF $^{\mathrm{TM}}$ & $Y$ & $Y$ \\
\hline DUPONT TM & $Y$ & $Y$ \\
\hline $\mathrm{DSM}^{\mathrm{TM}}$ & $Y$ & $Y$ \\
\hline L'OREAL $^{\text {TM }}$ & - & - \\
\hline ROQUETTE ${ }^{T M}$ & $Y$ & - \\
\hline SOLAZYME ${ }^{\mathrm{TM}}$ & y & Y \\
\hline
\end{tabular}

Figure 4. Identification by the 3 approaches, W, Q, G of an assignee (corporations and institutions) selection among ranking of 20 most prevalent assignees.

The concept clustering performed with the 3 platforms on the same number of patent documents as reported above is not as homogenous (Figure 3). There are 15 concepts that are common to at least two approaches, among 23 most dominant concepts ( 9 for W, 8 for Q and 6 for G). This is close to a yield of $66 \%$, if one may simplify and define such a metric from that dimension.

The 20 "predominant" (based on patent document counts) assignees' ranking is performed with each approach and summarized in Figure 4. Extracting 6 assignees (listed in Figure 4) out of the 20 provides 4 intersections, i.e. 4 assignees are common to the 3 approaches. This is somehow a yield of $2 / 3,66 \%$.

The two last analytics/metrics, key clusters and "predominant" assignees, provide a perspective on Bigger Data approaches as to their relation to IP and patent documents in particular, i.e. a count of 90 million around the world

\subsection{The "Biosourced" Matter}

"Renewable Chemicals Market worth 84.3 billion USD by 2020" from an estimated 
USD 49.0 Billion in 2015,

http://www.marketsandmarkets.com/PressReleases/renewable-chemical.asp, a potential of " $\$ 260$ billion for bio-based chemicals in 2012" was reported by McKinsey as per the American Chemistry Council, etc. Predictions are fluctuating. Entities such as biofuels, plant extracts, natural rubber, food/feed ingredients, oleochemicals, pharmaceutical ingredients, polyols, enzymes, bioplastics, etc. are part of those estimations.

New protein engineering methods, Bioinformatics \& high throughput screening, DNA sequencing/editing, Cellulosic depolymerization, Enzymatic polymerization, etc., are part of the activities associated to this growth.

Today, the chemical industry is still strongly dependent on fossil resources from which numerous chemical products (e.g. plastics, fertilizers, cleaners, cosmetics, paints, phytosanitary products, perfumes etc.) are manufactured. Especially, by the 1970's, organic chemicals derived from petroleum have tense vs. by 1970's or within captured more than $95 \%$ of the markets which would have probably been held by biosourced products [13].

However, due to the rarefaction of these fossil resources, the variability of their cost and associated geopolitical stakes, alternative resources are more and more considered for manufacturing products of the post-fossil era, consequently designing novel materials and methods with the objectives of reducing the fossil resources dependence and producing therefore more and more environmentally-friendly goods.

Among those alternatives, natural resources offer a wide range of resources including renewable biomass, which is largely produced with agriculture, silviculture and microbial systems: base ingredients being present in trees, plants, grasses, vegetables, algae, food wastes, animal manures and other organic wastes.

This renewable resource is composed of several natural polymers which, according to the hetero-atom of the main chain, are generally classified as:

- carbon-oxygen-containing polymers:

- sugar polymers which are source of 5- and 6-carbon sugars, (e.g., cellulose, hemicelluloses, starch, chitin, chitosan and pullulan);

$\circ$ phenolics such as lignins and humus;

- polyesters such as shellac;

- hydrocarbon polymers (e.g., natural rubber);

- carbon-oxygen-nitrogen/sulphur-containing polymers (e.g., proteins);

- carbon-oxygen-nitrogen-phosphorus-containing polymers (e.g., nucleic acids).

The diversity and the abundance of these products constitute a very big wealth and potential for:

- the replacement of materials actually stemming from fossil resources,

- the development of new materials which cannot be easily produced via the classical chemical methods,

- the development of new processes involving, for example, new generation of living and biochemical entities systems (enzymes or microorganisms) able to manage their chemical functionalities more efficiently, at lower temperatures and generating few- 
er emissions than conventional chemical processes.

Till now, opposite to fossil resources, only few industries (energy, construction, biofuels and pulp and paper processing) are using this massive reservoir of resources. Still, it is clear that the diversity of biomass feedstocks and the lack of conversion technology routes prevent an increased utilization of this natural resource.

Nevertheless, even if industrial production is still marginal, a strong research interest in converting underutilized biological materials into useful products constitute a significant innovation momentum. Figure 5 shows the main bio-based products which have been produced or extracted from renewable biomass through biological, chemical, thermal, or mechanical treatments and used for power, heat, fuel, biogas, biochemicals, and biomaterials.

This promoted the interest, particularly in the last decade, for the identification of biobased building blocks for a number of chemical intermediates and end products [14], useful to size the potential of both biosourced chemicals [15]-[19] and materials $[20]$.

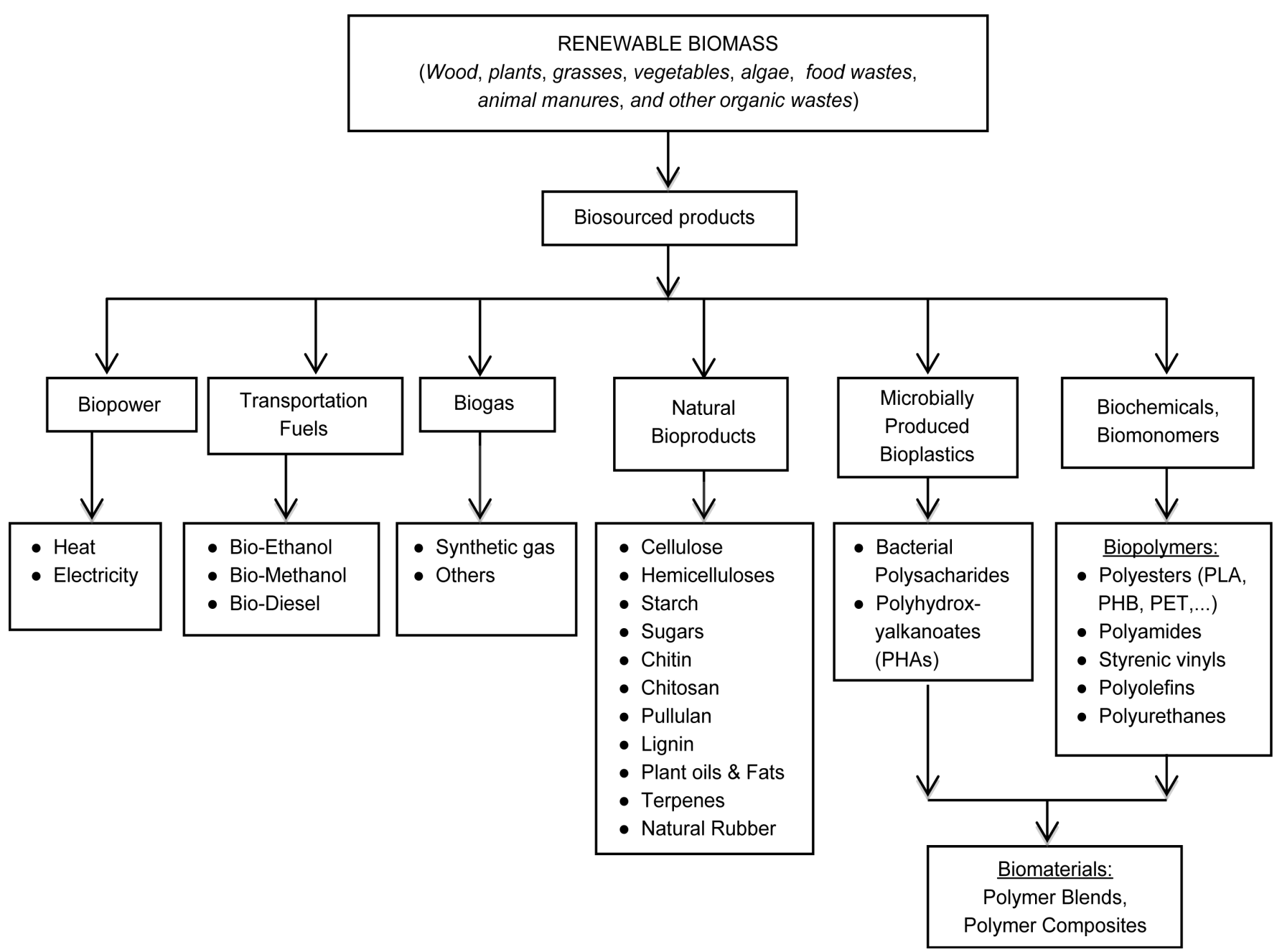

Figure 5. Classification of the main biosourced products and their utilization. 
These evaluations include conventional chemocatalytic processing, biorefinery concepts [19] and white biotechnology [18], which generally involve, enzymatic catalyses and microbial fermentations operated under soft conditions. Moreover selective reactions minimize both the consumption of inputs and the production of by-products.

It must be pointed out that the microorganisms used in such cases present rather lower efficiencies when they are isolated from their natural environment. During the past few decades, several cases successful overcome this challenge employing engineered microorganisms, i.e. metabolically engineered microbial hosts able to produce, at industrial levels, fuels and useful high-value chemicals with good yield [21]-[25].

In a good number of cases, biorefinery concepts account for [26]:

- effective and economical pretreatments to release the potentially fermentable sugars in lignocellulosic biomass; as well as alternative processes that enable more biomass carbon to be converted to desired products;

- relatively inexpensive enzymes (called "cellulases") to convert the sugar polymers to fermentable sugars;

- microbes that can rapidly and completely convert 5- and 6-carbon sugars or other biosourced compounds to chemicals intermediates and end products.

Metabolic engineering at system level has indeed contributed to developing efficient tools and strategies to improve microbial strains producing fuels and chemicals [27][29]. It integrates metabolic engineering with biological systems, synthetic biology and evolutionary engineering in the context of the entire bioprocess and aims to develop microbial strains on the basis of the multicriteria optimization of the whole bioprocess in order to maximize the production yield and productivity of the targeted chemical, while minimizing the consumption of inputs, the production of by-products and the overall operation costs.

For that purpose, intracellular metabolic fluxes are optimized using various molecular and high-throughput techniques which have been discussed and developed in numerous papers [30]-[41].

Moreover, cultivation conditions such as cultivation modes (i.e., batch versus fedbatch) [42], medium composition [43] [44], aeration [45] and pH, [46], are also considered. Optimization of these variables can significantly contribute to minimizing the overall operation costs.

Biobased products can be classified in three categories:

- commodity chemicals (including fuels),

- specialty chemicals used for power, heat, transportation fuels (such as ethanol, methanol, and biodiesel),

- biogas and specialty biochemicals including biomonomers and biomaterials.

Together with other recent and complementary reviews [19] [28] [29] [47]-[52] the present paper will be focusing on:

- biosourced chemicals (specialty chemicals, mainly monomers);

- advanced biosourced polymers, polymer blends and composites;

- new bioprocesses, mainly those related to the development of novel biocatalysts de- 
signed to overproduce those chemicals and materials, via metabolic engineering.

\section{General Considerations on Biosourced Materials and Chemicals}

Biomass cannot only provide fuel and energy, but also countless biomaterials and biochemicals that can be used as, among other things, paints, detergents, industrial adhesives, bioplastics, and composite materials.

Conventional biomaterials like wood and linen are used to build homes and make clothes.

Textile industry, uses mainly cellulose from ramie, cotton, wool, and flax.

In the paper industry, biomass in the form of pulpwood (lignocelluloses) is used to make paper and other packaging materials.

In the pharmaceutical industry, certain drugs and antibiotics can only be made from natural biomass materials through fermentation.

In the plastics industry, bioplastics have experienced rapid growth in the last few decades.

Biosourced materials have gained attractiveness in the last decades due to both ecological and economic concerns. They can be defined either as materials applied to a biological system or materials derived from a biological source. In some cases, these two approaches may be combined.

Biomaterials are also considered as structural, functional or multifunctional materials, operating in a specific, biological, environment. Most of them are polymer-based materials. In this context, biosourced polymers open a promising near horizon for a renewable source of new materials in a leaner low carbon society.

Applications include implants, tissue scaffolds and sensors. The study of such advanced biomaterials is majorly interdisciplinary. The related areas identified for future development embrace:

- bioresorbables and bioactive materials, together with novel manufacturing routes to achieve new properties in existing materials;

- new interfacial structures for the control of biomaterial-tissue interactions; and

- the integration of sensing systems into biomaterials for in-situ implant monitoring. Multiple strategies are adopted to produce new biosourced polymeric materials [53] [54]:

- Natural polymers can be extracted from biomass and, either used as obtained, or chemically modified to improve their properties. Some of these natural polymers, such as starch, cellulose, hemicelluloses can be hydrolyzed into sugars which are then converted to polymers by microorganisms (e.g. microbial polyesters).

- Natural monomers, such as sugars or aromatics, can be isolated and chemically modified to produce biomonomers with improved functionality. Those biomonomers can further be polymerized by conventional methods, giving rise to high-performance and functional polymers: 1) bioplastics (e.g., polylactic acid, polybutylene succinate, and polyethylene...) and 2) biothermosets (e.g., phenolic resins, epoxy 
resins, polyurethane resins, polyester resins.).

- Small biomolecules such as vegetable oils (e.g. canola, sunflower, pumpkin and tallow) can be extracted and then cross-linked by conventional methods to produce strong thermosetting plastics (e.g. vegetable oil thermosets).

- Polymers such as proteins can be isolated and suitably modified to get soya, beans, whey and horn-based proteins.

- Natural fibers from cellulose, starch, hemp can be extracted and/or modified to generate nanofibers, nanoparticles or nanocristals which can be used for preparing bio- and eco-composites using natural and/or synthetic polymeric matrices.

Figure 6 presents the global biosourced polymers and polymer blends production capacities in 2010 according to polymer type [55], indicating that starch and its blends, poly (lactic acid) and various types of polyhydroxyalkanoates (PHAs) are of the highest importance among bio-based and biodegradable polymers. The production of conventional polymers such as PE or PET based on renewable resources also gains more and more importance. These are not biodegradable, but their performance is the same as that of their fossil-based counter-parts.

Additionally, according to company announcements, by 2020 the most important bio-based polymers will be starch (1.3 Mt), PLA (0.8 Mt), PHAs ( $0.4 \mathrm{Mt})$ and bio-based $\mathrm{PE}(0.6 \mathrm{Mt})$ [56]. Figure 7 shows the evolution of the shares of biosourced production capacities in different regions (without Cellulose acetate and thermosets) from 2011 to 2020.

\section{Biosourced Specialty Chemicals}

The principal source of commodity and specialty chemicals are fermentable sugars that can be either produced directly from sugar feedstocks (e.g. corn, wheat, potato, sugarbeet, sugarcane and corresponding molasses) [40], or derived from polysaccharides and

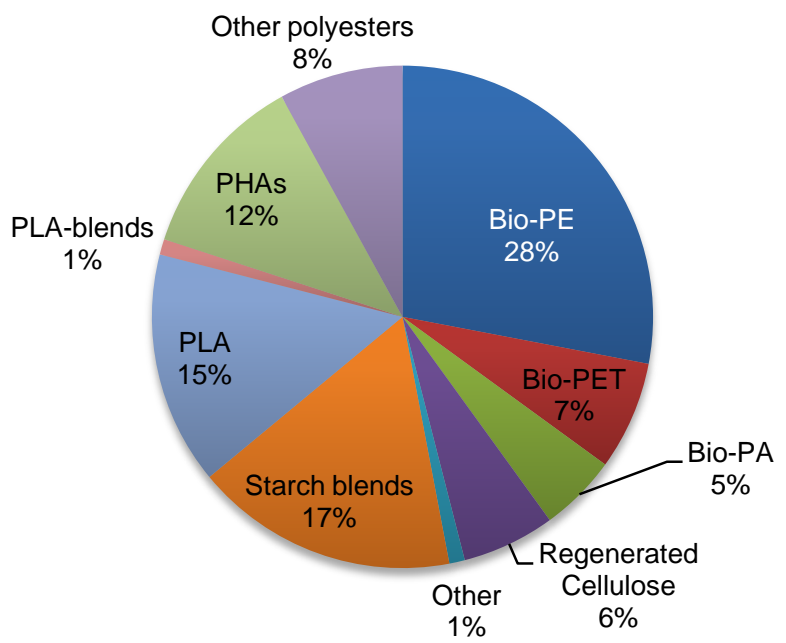

Figure 6. Global biosourced polymers and polymer blends production capacity in 2010 (PHAs: Polyhydroxyalkanoates, Bio-PE: Bio-based Polyethylene; Bio-PET: Bio-based Poly(ethylene terephthalate, Bio-PA: Bio-based Polyamide; PLA: Polylactic acid). 

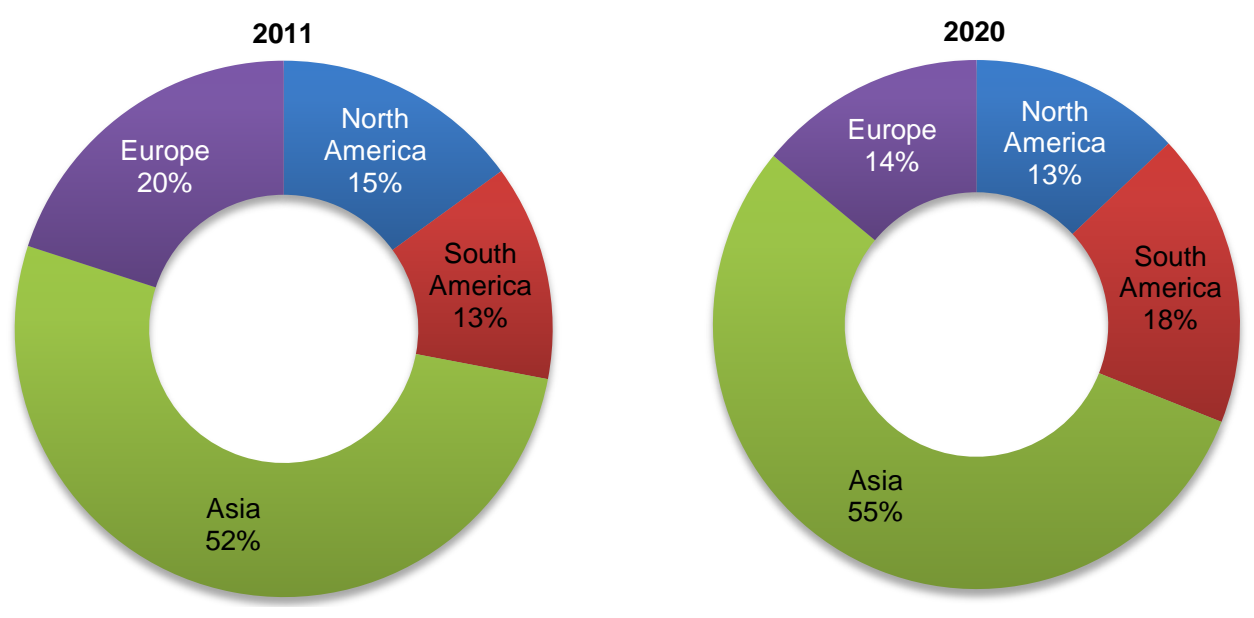

Figure 7. Evolution of the shares of biosourced production capacities in different regions of the world from 2011 to 2020 .

other lignocellulosic substances (e.g. plants, crop residues, waste paper.).

The most abundant sugars that are produced are: glucose, fructose, xylose, arabinose, lactose and sucrose. The main routes for their production are: dilute and concentrated acid hydrolysis, ammonia fiber expansion, steam explosion, supercritical fluids, enzymatic catalyses and microbial fermentations.

Furthermore, because sugars contain oxygen and petroleum feedstocks do not, there is the potential to derive oxygenated intermediate chemicals - such as ethylene glycol, adipic acid, and isopropanol-more readily from biological raw materials than from fossil sources. Production of such oxygenated chemicals by fermentation has the additional advantage of being inherently flexible.

Via biological or chemical conversions of these sugars, several building block chemicals can be produced and subsequently converted to a number of high-value bio-sourced commodity or specialty chemicals which are generally molecules with multiple functional groups possessing the potential to be transformed into new families of molecules useful for industrial applications in general transportation, textiles, safe food supply, environment, communication, housing, recreation, health and hygiene.

Bioethanol serves as a precursor to other organic chemicals required for production of many products such as paints, solvents, clothing, synthetic fibers, and plastics.

Table 1 shows a list, established in 2004 by the US department of Energy (DOE), of $30 \mathrm{C} 1$ to $\mathrm{C} 6$ representative building block candidates, which could be generated by/during sugars fermentation. Those candidates are able to serve as building blocks for more complex secondary and intermediate chemicals [19].

Another source of speciality chemicals is lignin which, besides cellulose and hemicelluloses constitutes approximately $25 \%$ - $30 \%$ of wood. Lignin presents many challenges for use in the biorefinery. It has indeed a really important chemical potential as the sole abundant source of bio-based aromatic compounds.

However, unlike cellulose, lignin has a high degree of variability in its structure which differs across biomass sources and the recovery processes [57]. Nevertheless, de- 
spite those difficulties, ongoing studies covering the purification [58] [59] and the deand re-polymerization of lignin [60]-[62], as well as the lignin application in the material industry are been developed.

Lignin processing also can produce low-molecular weight aliphatics (C1-C3, etc.) along with aromatics. Residuals may include formic or acetic acids as well as aliphatics and olefins. Alternatively, those materials can be dehydrogenated to provide low-molecular weight olefins. Table 2 presents the main existing lignin transformation technologies and the corresponding chemicals that can be obtained.

Some biobased chemicals such as vegetable-oils, based inks and fatty acids are becoming competitive [63] on the related markets.

Increasingly, niche markets will be scouted for a wide array of plant chemicals (e.g., chiral compounds) not avail able from the petrochemical markets.

\section{Biosourced Polymers and Monomers}

The following section is mainly oriented towards metabolic and pathway engineering that has been studied for the development of novel biocatalysts able to help shape

Table 1. Representative building blocks of chemicals that can be produced from sugars.

\begin{tabular}{cc}
\hline $\begin{array}{c}\text { Number of } \\
\text { carbon atom }\end{array}$ & Building blocks \\
\hline 1 & Carbon monoxide \& hydrogen (syngas) \\
2 & acetic acid, acetic anhydride \\
3 & Acetoin, aspartic acid, fumaric acid, 3-hydroxybutyrolactone, malic acid, \\
succinic acid, threonine & Arabinitol, furfural, glutamic acid, itaconic acid, levulinic acid, proline, xylitol, \\
xylonic acid & Aconitic acid, citric acid, 2,5 furan dicarboxylic acid, glucaric acid, lysine, \\
levoglucosan, sorbitol
\end{tabular}

Table 2. Main Lignin Transformations and obtained chemicals.

\begin{tabular}{cc}
\hline Transformation technology & Resulting products \\
\hline Hydrogenolysis & Phenols and aromatic hydrocarbons \\
Alkaline hydrolysis & Phenols, substituted phenols \\
Mild oxidation in alkaline medium & Vanillin, \\
Microbial conversions & Vanillic, ferulic, coumaric and other acids \\
Alkali fusion & Phenolic acids, catechol \\
Strong oxidation & Organic acids: benzoic, toluic, methoxybenzoic, \\
Pyrolysis & acetic and formic acids. \\
\hline
\end{tabular}


the future of the biopolymers industry.

There are three principal ways to obtain bio-sourced polymers using renewable resources [64]:

- Extraction, purification and eventually partial modification of natural polymers produced by plants, (e.g., cellulose, starch, chitin and chitosan, pullulan, lignin...);

- Direct production of biosourced polymers by microorganisms (e.g., polyhydroxyalkanoates, poly- and oligo-saccharides);

- Prodution of bio-sourced monomers (e.g., sugars) by fermentation followed by further modification and polymerization.

\subsection{Natural Polymers Produced by Plants}

Cellulose [65] [66], starch [67] [68], chitin and chitosan [69], proteins (soya protein, gelatin, casein, etc. [70]-[72]) and their derivatives offer a wide range of properties and applications which are briefly summarized hereafter:

- Cellulose is produced in wood and plants such as hemp, flax, jute, ramie and cotton. It is also synthesized by algae, tunicates and bacteria. For many years it has been used as engineering material in many industrial processes such as pulp and papermaking and manufacture of artificial textile fibres (e.g. organic and inorganic esters, alkyl, hydroxy alkyl and carboxyl alkyl ethers) which are used as important components in coatings, optical films, foodstuffs, pharmaceutics, cosmetics, additives in building materials etc. On the other hand, more technical applications have been recently explored using nanocrystals [9] [73]-[75] or grafted cellulosic materials [76]-[78]. Nowadays it is also abundantly studied as a second-generation bio-fuel.

- Starch is abundant in wheat, rice, corn, potato, etc... Essentially, it consists of the linear polysaccha ride amylose and the highly branched polysaccharide amylopectin. Applications of thermoplastic starch polymers include films, overwraps, packaging materials and sanitary products. It is also used for food and feed (as well for its food engineering value as thickener and emulsifier) [79], as cosmetics, pharmaceuticals and paints. It has found application also in textile and paper industries and as a biodegradable packaging material [80]-[82]. More recently it has been investigated as a first-generation bio-fuel.

- Chitin and chitosan are abundant natural amino polysaccharides derived from shells of prawns and crabs. Chitosan is a very attractive material for applications as biomaterial in medical devices and as pharmaceutical [83] [84] and cosmetic ingredient for example in the skin care industry.

- Pullulan is a linear water-soluble, low viscosity, polysaccharide consisting of maltotriose units connected by $\alpha-1,6$ glycosidic units obtained by the fermentation of simple sugars using Aureobasidium pullulans. Pullulan is used as flocculant, blood plasma substitute, drug and gene delivery, tissue engineering, wound healing etc... [85], adhesive [86]-[88]. It is extensively used in the food industry as a low calorie food additive and as a material for food preservation owing to its excellent oxygen 
barrier property and good moisture retention.

- Lignin is a phenolic polymeric material formed, through a metabolic pathway, from the phenolic precursors named $p$-hydroxycinnamyl alcohols, such as $p$-coumaryl alcohol, coniferyl alcohol and sinapyl alcohol. It is composed of randomly branched phenylpropenyl (C9) building blocks, connected through carbon-carbon and carbon-oxygen (ether) bonds [89]-[92]. Applications are extensive, but until now have been used in very limited volumes. The most known examples belong to academic research. Some reported applications clearly show that lignin has a great potential as:

- a reinforcement material in composites including thermoplastic, thermosets, rubber, foams, bioplastics, nanocomposites, and low-cost carbon fibers, [93],

○ new generation of polyols, macromonomers in polyester, urethane [94] and epoxy polymers.

\subsection{Biosourced Polymers Produced by Microorganisms}

\subsubsection{Polysaccharides}

Microorganisms (mainly bacteria) can produce natural polymers from sugars. For example, acetobacter xylinum, Rhizobium and sarcinaare are able to produce pure cellulose (i.e. without lignin and hemicelluloses). This bacterial cellulose is characterized by a high mechanical strength and can be used to produce articles with relatively high strength, wound care healing system $\left(\mathrm{XCell}^{\circledR}\right)$ [95], acoustic diaphragms, paints, oil gas recovery, adhesives, medical films (Biofill ${ }^{\oplus}$, Bioprocess ${ }^{\circledR}$, and Gengiflex ${ }^{\oplus}$ ) [96].

Other polysaccharides are also produced, [97], involving:

- Bacteria (e.g., dextrans and derivatives, hyaluronan and hyaluronic acid by streptococcus, glycogen by E. Coli, Clostridia, Bacillus, and Streptomyces, alginate by Pseudomonas and Azotobacter, glucuronan by Rhizobium and Pseudomonas),

- Fungi (e.g., pullulan by Aureobasidium, Pullularia and Dematium, Chitin and chitosan by Basidomycetes, Ascomycetes...),

- Algae (e.g., alginate by Phaeophyceae and carragenan by Rhodophyceae).

\subsubsection{Polyhydroxyalkanoates}

A number of natural biosourced polymers produced by microorganisms are useful as bioplastics.

The most important are polyhydroxyalkanoates, (PHAs), which are a family of biodegradable linear polyesters that can be directly produced by varieties of bacteria using several renewable waste feedstocks. Well-known bacterial PHA producers include species of Ralstonia [98], Bacillus [99] and Pseudomonas [100], as well as phototrophic cyanobacteria [101].

Although PHAs are efficiently produced by microbes via naturally evolved biosynthesis routes, expressing the requisite pathway enzymes from various natural producers has also enabled their production at high levels in recombinant Escherichia coli, a more tractable host platform [102]. Bacteria have been engineered to achieve PHA biosynthesis at up to $80 \%$ of cell dry weight and at productivities as high as $4 \mathrm{~g} / \mathrm{L}-\mathrm{h}$ from sub- 
strates such as glucose [103].

A generic process to produce PHA by bacterial fermentation involves fermentation, isolation, and purification from fermentation broth.

More than 150 PHA monomers have been identified as the constituents of PHAs [104]. Such diversity allows the production of bio-based polymers with a wide range of properties, tailored for specific applications.

Poly-3-hydroxybutyrate was the first bacterial PHA identified. It has received the greatest attention in terms of pathway characterization and industrial-scale production. It possesses similar thermal and mechanical properties to those of polystyrene and polypropylene [105]. However, due to its slow crystallization, narrow processing temperature range, and tendency to "creep", it seems not attractive for many applications, requiring development in order to overcome these shortcomings [106].

Several companies have developed PHA copolymers with typically $80 \%$ to $95 \%$ (R)-3-hydroxybutyric acid monomer and $5 \%$ to $20 \%$ of a second monomer in order to improve the properties of PHAs.

PHAs can be processed in classical polymer-processing equipment and can be converted into a plurality of injection-molded components: film and sheet, fibers, laminates, and coated articles, etc. These materials are suitable for a wide range of food packing applications including caps and closures, disposable items and products such as housewares, cosmetics, and medical packaging [107]. PHA and its copolymers are widely used as biomedical implant materials. PHAs can also be used in drug delivery due to their biocompatibility and controlled degradability.

In spite of numerous advantages, PHA production also suffers from other inherent shortcomings which may ultimately impede their long-term and wide-spread utility. For instance, while their biodegradable nature can help reduce municipal waste, this attribute renders PHAs less suitable for use in applications requiring long term durability and/or environmental exposure. As all PHAs are thermoplastic polyesters the achievable range of physicochemical and material properties, though diverse, is inherently limited. Moreover, PHA chain length and purity are difficult to tune and control with high quality assurance.

\subsection{Microbial Production of Biosourced Monomers (Biomonomers) and Corresponding Polymers}

As for many specialty chemicals, one can distinguish two classes of biosourced monomers of industrial interest.

The first can be produced from natural compounds with the aid of catalytic furtherprocessing steps. For example, the natural fermentation of sugars yields ethanol which can undergo dehydration to ethylene over a solid acid catalyst [108] [109], before later being polymerized to poly(ethylene) or its co-polymers. Braskem ${ }^{\mathrm{TM}}$ is taking this approach to convert sugarcane-derived ethanol to bioplastics in Brazil [110].

The second class of biomonomers, which, as previously stated, is a central focus of this review, concerns those compounds that themselves are directly suitable for poly- 
merization into bioplastics. Wherever possible, the microbial production of "drop-in compatible" biomonomers by this approach is advantageous because, it ensures a seamless interface between emerging biotechnologies and the existing polymer industry.

The list of monomers that can be obtained from biomass is vast and has been recently reviewed [111]-[113].

In general, biosourced monomers can be divided according to their biomass origins as follows:

- oxygen-rich monomers namely carboxylic acids, polyols, dianhydroalditols, and furans,

- hydrocarbon-rich monomers including vegetable oils, fatty acids, terpenes, terpenoids and resin acids,

- hydrocarbon monomers such as bio-ethene, bio-propene, bio-isoprene and bio-butene, and

- non-hydrocarbonmonomers, namely carbon dioxide and carbon monoxide, as critically discussed by Yao and Tang in a recent perspective [112].

Those monomers are suitable to produce different types of important biosourced polymers (e.g. polyesters, polyamides, polycarbonates, polyurethanes, polyethers) [114]. In this category, polyesters used to be the most popular.

Historically, the main studied monomers were bi-functional molecules, such as:

- lactic acid which is able to self-condense for the production of polylactic acid (PLA);

- succinic acid which represents a potential bio-based building block able to be transformed into several commodity chemicals (THF, hydroxysuccinimide etc.) or specialty chemicals (organic acids such as fumaric, itaconic etc. Figure 8) and to produce polymers (polyamides, polyesters and poly(ester amide)s),

- hydroxyacids such as 3-hydroxypropionate (3HP), 3-hydroxybutyrate (3HB), and 3-hydroxyvalerate $(3 \mathrm{HV})$ which are used to produce polyesters,

- diols such as 1.3-propanediol (PDO) leading to Dupont’s Sorona ${ }^{\circledR}$ after condensation with terephthalic acid.

More recently, some other monomers have been developed. The attraction of production of well-known materials from renewable feedstock led to studies of the use of ethanol for the production of bio-based polyethylene (PE), of caprolactam and muconic acid for the production of polyamides (PA) and of isobutylene for the synthesis of polyisobutylene.

Biomonomers offer several important advantages, including:

- improved control over the final polymer structure and purity,

- the ability to synthesize non-natural copolymers,

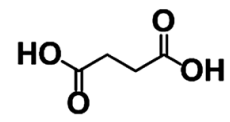

Succinic acid<smiles>O=C(O)C=CC(=O)O</smiles>

Fumaric acid

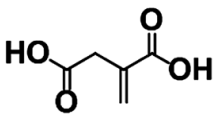

Itaconic acid

Figure 8. The chemical structures of succinic, fumaric and itaconic acids. 
- allowing products to be excreted from cells which ultimately streamlines downstream recovery and purification.

\subsubsection{Biosourced Aliphatic Polyesters and Corresponding Monomers}

\section{1) Lactic Acid and Poly(Lactic Acid)}

Lactic acid is an important molecule used in the food, cosmetic, pharmaceutical, and chemical industries. [115] [116] It has received increased attention for the production of the biodegradable polyesterpoly(lactic acid) -PLA-. Lactic acid bears an asymetric carbon atom leading to $(\mathrm{L}(+)$ and $(\mathrm{D}-)$ stereoisomers which have both been produced as optically pure stereroisomers by metabolically engineered E. coli [117]-[119].

Until now PLA has been produced in a two-step fermentation and chemical process of polymerization, which is both complex and expensive. Recently, through the use of a metabolically engineered strain of $E$. coli, a one-stage process was developed which produces polylactic acid and its copolymers through direct fermentation. For this, E. coli was engineered by modifying the substrate specificity of PHA synthase of a Pseudomonas sp. and promoting the production of lactyl-CoA, the monomer precursor, by introducing an evolved propionate CoA-transferase from Clostridium propionicum [120] [121]. This makes the renewable production of PLA and lactate-containing copolymers cheaper and more commercially viable.

However, penalized by its cost and also some weaknesses in thermo-mechanical properties (mainly heat resistance), PLA is considered as one of the most promising bioplastics for the substitution of the petroleum-based polymers in materials and packaging applications [122]-[124].

Currently, the main industrial PLA companies are Nature Works, supported financially by Cargill and PTT Global Chemicals, which has announced a production of 140 000 metric tons of PLA per year. Nature Works already produces more than 20 different grades of their Ingeo ${ }^{\mathrm{TM}}$ PLA bioplastics portfolio providing structures that range from amorphous to crystalline and uses extending from films to foams.

\section{2) Succinic Acid}

Succinic acid is mainly produced by chemical processes from n-butane/butadiene via maleic anhydride formation, utilizing the C4-fraction of naphtha. It is also one of the fermentation end-products of anaerobic metabolism. Many different microorganisms have been tested among which Anaerobiospirillum succiniciproducens, Actinobacillus succinogenes, Mannheimia succiniciproducens [125] and recombinant Escherichia coli strains [126] appeared as very efficient natural overproducers.

As previously mentioned, succinic acid is a key building block for a wide range of secondary chemicals used in the chemical, pharmaceutical, food and agricultural industries. Offering cost-competitiveness and superior functionality and performance, bio-derived succinic acid can replace conventional petroleum-based succinic acid, can substitute for other chemicals like adipic acid in applications such as the production of polyurethanes, and can serve as the starting material for the production of high-value, high-volume chemicals. Myriant (http://www.myriant.com) and BioAmber (http://www.bio-amber.com) have generated breakthrough biotechnology steps in 
commercial production in this area. These companies produce succinic acid biochemically from glucose using a genetically engineered organism [127]. The bio-based succinic acid is cost competitive and offers superior functionality and/or performance with a better environmental footprint.

In addition to succinic acid the synthesis of polyamides, polyesters and poly(ester amide)s requires diamines or diols, these compounds being possibly obtained by chemical conversion of succinic acid.

The first commercial bioplastics derived from this biomonomer is likely to be polyamide-5,4 [128] and poly(butylene-co-succinate) (PBS) [129], a biodegradable thermoplastic suitable for extrusion, injection molding, thermoforming, and film blowing [130].

Other polyesters (homo- and copolyesters) are manufactured by polycondensation of dicarboxylic esters with diols, [131]-[134]. A second way is the direct polycondensation of dicarboxylic acids with diols [135]-[140]. However, as the thermal and mechanical properties of those biosourced polyesters are not always optimal for industrial applications, attempts have been made to improve those properties; for example by the introduction, through copolymerization, of amide groups into the main polyester chains provided that these comonomers promote strong intermolecular hydrogen-bond interactions. For example poly(ester amide)s, exhibiting high performance and processing ease, are manufactured from $\varepsilon$-caprolactam, adipic acid and 1,4-butanediol. Also, novel biodegradable biosourced copolymers, with a periodic sequence structure of ester and amide units, were obtained from succinic acid, dialkyl ester, 1,4-butanediol, and 1,4butanediamine [141].

\section{3) Hydroxyacids}

The three previously mentioned hydroxylacids $(3 \mathrm{HP}, 3 \mathrm{HB}, 3 \mathrm{HV})$ have been produced microbially from renewable resources via pathway engineering. $3 \mathrm{HP}$ can serve as polyester monomer and can be used to produce several commodity and specialty chemicals such as acrylic acid, acrylamide, propiolactone, malonic acid, and 1,3-propanediol.

Several enzymatic methods have been promoted to produce microbial 3HP [142][145] using E. coli. Each method has its own limitations and represents platforms from which subsequent improvements can now be made via continued strain development.

Microbial production of ( $R$ )-3HB by recombinant E. coli was first reported by Gao et al. in 2002 [143].

Other authors [144] [145] produced $(R)$ - and $(S)$-3HB isomers and subsequently enantiomerically pure stereoisomers of the 5 -carbon $\beta$-hydroxyacid $3 \mathrm{HV}$ with the potential to develop bioplastics with a broad range of properties.

\section{4) Diols}

Short-chain diols (e.g., 1,3-propanediol (1,3-PDO), 1,4-butanediol (1,4-BDO)) which are suitable for bioplastics applications have been produced microbially via both natural and engineered pathways.

$1,3-P D O$ is one of the oldest known products of anaerobic fermentation. Several stu- 
dies were accomplished in order to achieve production of 1,3-PDO by fermentation of corn sugar using engineered strains. Two different approaches were attempted: 1) expression of genes for the glycerol production from glucose in 1,3-PDO-producing strains and 2) the expression of the 1,3-PDO-producing genes in the glycerol-producing strains. The first approach was found to be more efficient and has been applied industrially by Genencor [146] [147], a Danisco's subsidiary.

1,3-PDO is separated from the fermentation broth and then used in direct products formulations or as ingredient in polymers.

On the other hand, DuPont performed the polymerization of 1,3-PDO with terephthalic acid to obtain poly(trimethylene terephtalate) called Sorona ${ }^{\circledast}$ (Figure 9) [148]. This partially bio-based polymer is mainly used in different fibre applications such as floor coverings and sportswear. Two other grades of $100 \%$ biosourced PDO ${ }^{\mathrm{TM}}$ (Zemea and Sustera ${ }^{\circledast}$ ), manufactured by DuPont Tate and Lyle are used in cosmetics, personal care and home cleaning products.

1,4 butanediol is a key chemical building block for polyesters, co(polyester ether)s, polyurethanes and other copolymers. In late 2007, Genomatica, a privately-owned chemical processing company based in San Diego, California, began developing a new process for the direct production of 1,4-BDO starting from renewable feedstocks. Genomatica developed a genetically-modified strain of $E$. coli bacteria to convert a variety of sugars (e.g. glucose, sucrose, biomass sugars) into 1,4-BDO through fermentation along with subsequent recovery and purification operations. Genomatica demonstrated that 1,4-BDO made with Genomatica's process technology can be used as a replacement for conventional 1,4-BDO produced from fossil fuels for example for its copolymerization with butylene terephtalate. Indeed, no adverse impact on the purity and the performance of the obtained high performance thermoplastic copolyester was observed [41].

\subsubsection{Biosourced Aromatic Polyesters and Corresponding Monomers}

Aromatic polyesters have a high market share, essentially due to their high performance properties (high molecular weights, favorable melting and glass transitions, or adapted mechanical behaviour). Important commercial examples of aromatic polyesters include the high performance thermoplastic PET and poly(butylene terephthalate) (PBT).

The plastics department of DuPont ${ }^{\mathrm{TM}}$ made available partially renewable terephthalate based polyesters, namely Sorona ${ }^{\circledR}$ EP (PTT) and Hytrel $^{\circledR}$ RS (PBT-b-PTMG), which contain, respectively, 1,3-PDO derived from corn sugar and polyether glycols made

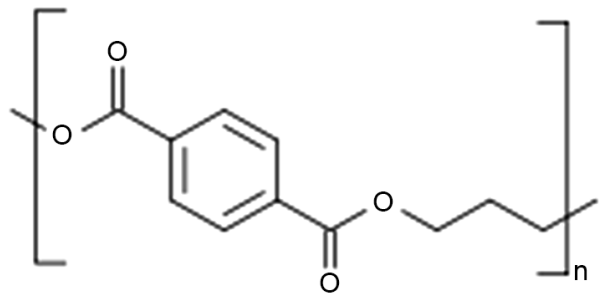

Figure 9. Chemical structure of sorona ${ }^{\circledR}$. 
from non-food biomass [149]. The former is mainly applied in electrical/electronic devices, automotive components, appliance parts, furniture, food contact compliant grade materials, whereas the latter finds key applications in hose and tubing, air bag doors, energy dampers, sporting goods, among others [149].

Carbohydrates and lignin are the major sources of aromatic biomonomers [150], namely furan compounds (e.g., 2,5-furandicarboxylic acid (FDCA) and derivatives) and lignin-based compounds such as vanillic, caffeic and ferulic acids [151] [152].

The publications presented in the following paragraphs concern renewable-based aromatic polyesters and co-polyesters obtained from these two families of products.

\section{1) Furan-Based Polyesters}

FDCA is used as a substitute of terephthalic acid and isophthalic acid in the synthesis of polyesters. It results from the catalytic oxidation of 5-hydroxymethylfurfural (HMF), which is obtained from the acid catalysed-dehydration of C6-sugars, (Figure 10).

FDCA can be transformed into several derived monomers such as 2,5-furandicarboxylicdichloride, bis(hydroxyethyl)-2,5-furandicarboxylate, and bis(hydroxypropyl)2,5-furandicarboxylate. The polymerisation of those renewable monomers has generated a wide diversity of high performance thermoplastic biopolyesters which have been covered in several reviews [153]-[155]. Table 3 highlights some of the most relevant.

\section{2) Lignin-Based Polyesters}

The main monomer precursors used for the synthesis of aromatic polyesters are vanillic, caffeic and ferulic acids. Table 4 gives some representative examples of those polyesters.

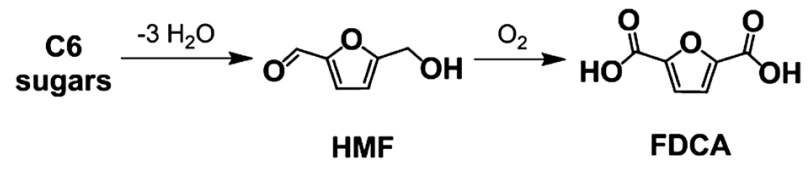

Figure 10. Conversion of C6-sugars into FDCA.

Table 3. Examples of furan-based aromatic polyesters.

\begin{tabular}{|c|c|c|}
\hline Polyester & Monomers & References \\
\hline PEF and FDCA based co(polyesters) & $\begin{array}{l}\text { FDCA and derivatives } \\
+ \text { Ethylene glycol or other diols }\end{array}$ & [156]-[158] \\
\hline FDCA based co(polyesters) & FDCA + Ethylene glycol + 1,4-butylene glycol & [159] \\
\hline PET-ran-PEF copolyesters & $\begin{array}{l}\text { bis(hydroxyethyl)-2,5-furandicarboxylate } \\
\quad+\text { bis(2-hydroxyethyl) terephthalate }\end{array}$ & {$[160]$} \\
\hline Poly(butylene 2,5-furandicarboxylate) & FDCA + 1,4-butanediol & [161] \\
\hline Poly(octylene furanoate) & DMFD + 1,8-octamethylenediol & [162] \\
\hline $\begin{array}{l}\text { Poly(butylene succinate-co-butylene } \\
\text { furandicarboxylate) copolyesters }\end{array}$ & FDCA + Succinic acid + 1,4-butanediol & [163] \\
\hline
\end{tabular}

PEF: poly(ethylene 2,5-furandicarboxylate); FDCA: 2,5-furandicarboxylic acid; DMFD: 2,5-dimethylfuran-dicarboxylate. 
Table 4. Examples of representative lignin-based aromatic polyesters.

\begin{tabular}{ccc}
\hline Polyester & Involved Monomers & References \\
\hline poly(dihydroferulic acid) (PHFA) & 4-acetyl dihydroferulic acid (1) & {$[164][165]$} \\
$\begin{array}{c}\text { Poly(alkylene 4-hydroxybenzoate)s, } \\
\text { poly(alkylene vanillate)s, and } \\
\text { poly-(alkylene syringate)s }\end{array}$ & Corresponding alkylene hydroxybenzoates, & {$[166]$} \\
Thermoplastic aromatic polyesters & vanillates and syringates \\
poly(caffeic acid-co-lithocholic acid) & vanillin + fatty acid derivatives & {$[167]$} \\
poly(caffeic acid-co-hydroxycapric acid) & caffeic and lithocholic acids & {$[168]$} \\
\hline
\end{tabular}

(1) Obtained by reaction between vanillin and acetic anhydride.

\subsubsection{Biosourced Polyamides}

Biosourced polyamides have high growth potential with their promising mechanical and thermal properties [170]-[172]. They are synthesized from two or more monomers or comonomers, which belong to amino acid, cyclic amide (lactam), dicarboxylic acid, and diamine families. Fatty acids present in vegetable oils can be converted by simple reactions into suitable bifunctional monomers for the production of polyamides by a simple polycondensation process. Among most known biomonomers are 11-aminoundecanoic acid and sebacic acid produced by conversion of ricinoleic acid derived from castor oil. Typically, raw castor oil is hydrolyzed to give ricinoleic acid, which in turn is converted to sebacic acid in a reaction with potassium or sodium hydroxide at high temperature [173]. The 1,12-dodecanedioic can be potentially obtained by an $\omega$ oxidation process of lauric acid catalyzed by yeast strain [174]. Undecane-1,11-dicarboxylic acid and 11-aminoundecanoic acid appear to be potential monomers, too [175]. Tetramethylenediamine (putrescine), and pentamethylenediamine (cadaverine) are naturally occurring diamines used for the production of bio-polyamides. They are produced by microbial biosynthesis, using $E$. coli, by decarboxylation of amino acids (lysine or ornithine) and polymerized with naturally-occuring biomonomers such as succinic acid. Polyamides derived from cadaverine possess high melting points and low water absorption [176]. PA-5,4 and PA-5,10 have been proposed as bio-based alternatives to several petroleum-derived PAs [176] [177].

$P A$ homopolymers are produced using amino acid monomers such as 4- or $\gamma$-aminobutyrate (GABA) [178] which can be naturally produced from L-glutamate by $E$. coli expressing glutamate decarboxylase. Other bifunctional monomers can be synthesized by complementary hydrobromination of fatty acid methyl esters and further modification [179]. PA-6 was first synthesized from caprolactam by Wallace Carothers in 1935 when he was working for DuPont ${ }^{\mathrm{TM}}$. Then, it became one of the most popular polymers worldwide, reaching an annual production of nearly 2 billion tons. Its main producer is the Dutch DSM who has pioneered the biotechnological approach for the production of bio-caprolactam from the $\alpha$-ketoglutarate.

The first patented step of this synthesis was the cyclization of 6-aminocaproic acid to 
caprolactam [180], followed by the transformation of $\alpha$-ketopimelate into 6-aminocaproic acid [181] and finally the "elongation" of $\alpha$-ketoglutarate to the $\alpha$-ketopimelate [182]. This latter step is of particular interest, as it uses the iteration of acetyl-CoA's addition-dehydration-hydrogenation-decarboxylation cascade ending by the addition of one carbon atom to the main skeleton, which can be repeated until $\alpha$-ketosuberate (three carbons) have been added to the initial chain.

\subsubsection{Biosourced Styrenic Vinyls Polymers}

Today, styrenic vinyl polymers e.g., polystyrene, acrylonitrile-butadiene-styrene, styrene-acrylonitrile, styrene butadiene rubber, etc. are produced using petroleum-derived monomers. However, recent engineering of novel enzymatic routes are currently applied to obtain both p-hydroxystyrene (pHS) and styrene from glucose. The engineered pHS biosynthesis pathway [183] stemmed from L-tyrosine as its immediate endogenous precursor. Pseudomonas putida S12 was successfully used to overproduce pHS.

More recently, a novel pathway was engineered to enable E. coli to produce styrene directly from glucose [184].

\section{Biosourced Polymers Blends and Composites}

Biopolymers have indeed high potential and several advantages, but also possess some drawbacks. As clearly shown in previous sections their production capacity is important, but compared to commodity polymers their properties are often inferior. As a consequence, techniques have been developed to improve those properties and also to achieve the property combinations required for specific applications. Those techniques include (i) plasticization, chemical modification, blending, addition of compatibilizers, to increase the miscibility of incompatible polymers, to decrease the interfacial energy and then stabilize polymer blends, (ii) incorporation of fillers and reinforcements, to yield biosourced nanocomposites.

Plasticization is often used to improve the processability and/or other properties required for a specific application. Numerous studies and patents describe the plasticization of both natural and synthesized biopolymers e.g. starch [185] [186], polylactic acid [187]-[193], poly(3-hydroxybutyrate) [194] [195].

Chemical modification can be realized by specific modifications of the components for example by changing the comonomer type and amount [196] by esterification or transesterification grafting with multifunctional compounds 197].

Blending is a common process used to modify the properties of biopolymers. It is clearly established that incorporation of relatively low cost natural biopolymers into biodegradable synthetic polymers provides a way to reduce the overall cost of the material and constitutes a method to modify both the properties and the degradation rates. For example, the impact strength of inherently brittle polymers, mainly aliphatic polyesters, can be improved considerably by this approach. The number of papers on the blending of biopolymers is vast.

PLA and starch are the most often studied materials. Table 5 gives the most representative starch based polymer blends which were obtained with PLA and PCL. 
Table 5. Examples of starch based polymer blends and targeted modified properties.

\begin{tabular}{|c|c|c|c|}
\hline Blend components & Additive & Improved properties & Reference \\
\hline Starch/PLA & PEG (plasticizer) & - Tg and crystallinity & [197] \\
\hline Starch/PLA & MDI (coupling agent) & -Microstructure, tensile strength, elongation & [198] \\
\hline Starch/PLA & MA & -Tensile strength, elongation & [199] \\
\hline Starch/PLLA & - & -Tensile strength and elongation & [200] \\
\hline $\begin{array}{c}\text { High-amylose } \\
\text { starch/PLLA, } \\
\text { (starshaped PLLA)/PCL }\end{array}$ & - & -Mechanical properties, toughness & [201] \\
\hline Gelatinized starch/PLA & $\mathrm{H}_{2} \mathrm{O} /$ Glycerol & $\begin{array}{l}\text {-Crystallinity, interfacial adhesion, } \\
\text { Mechanical properties, toughness }\end{array}$ & [202] \\
\hline Starch/PCL & - & -Young's modulus, strength, elongation & \\
\hline Starch/PCL & $\begin{array}{c}\text { Various \% of } \\
\text { High-amylose starch }\end{array}$ & -Biodegradation rate & [203]-[207] \\
\hline Starch/PCL & - & $\begin{array}{c}\text {-Structure, interfacial adhesion, } \\
\text { mechanical properties }\end{array}$ & \\
\hline Starch/PCL & Starch-g-PCL & -Tensile strength, elongation, Young's modulus & [208] \\
\hline Starch/PCL & MA modified PCL & Resilience & [209] \\
\hline
\end{tabular}

PEG: Polyethylene-glycol; MDI: methylenediphenyl diisocyanate; MA: Maleic anhydride; PCL: Poly(e-caprolactam); PLLA: Poly(L-Lactic acid).

Blending of biodegradable polymers is advantageous mainly in packaging and agriculture, although medical applications can significantly benefit from this. Commercial grades of fully biopolymer blends have already found application in the former two areas. In short service life applications, the environmental advantage, i.e. the compostability of the products is the most important requirement generally fulfilled by all of these grades. Those are mainly starch and PLA based materials modified by blending with different types of polyesters, e.g. aliphatic-aromatic copolyesters (AACs). For long-term applications, several hybrid blends based on starch and poly(lactic acid), which contain conventional polymers and biopolymers are present on the market.

Some other blends elaborated with various biosourced polymers are given in Table 6. Advanced biomaterials, and biopolymer blends in particular, are being used increasingly in biomedical applications in various forms replacing traditional engineering materials, the characteristics of which generally fail to meet the high standards of modern human healthcare approaches [228]. Significant areas where advanced biomaterials are applied involve the production of nano- and micro-particles for drug delivery and controlled release applications [229], two-dimensional structures, e.g. membranes for wound dressing [230], porous matrices (scaffolds) for tissue engineering purposes, to support cells and promote their proliferation [231]. Multi-component, heterogeneous polymeric systems, blends [232]-[234], micro- [235] and nano-composites [236], play an important role addressing such complex expectations, as the properties of these can 
Table 6. Other engineered biopolymer blends.

\begin{tabular}{cc}
\hline Blend components & Reference \\
\hline Poly(3-hydroxybutyrate-co-3-hydroxy-hexanoate)/Poly(vinyl phenol) & {$[210]$} \\
Thermoplastic phenol formaldehyde resin/(PCL) & {$[211]$} \\
Poly(3-hydroxybutyrate-co-3-hydroxyhexanoate)/PLA & {$[212]$} \\
Polyhydroxybutyrate(PHB/PLA) & {$[213]$} \\
PLA/Poly(butylene succinate) (PBS) & {$[214]$} \\
PHB/PCL & {$[215]$} \\
PLA/(PEG) & {$[216]$} \\
PHB/PBS & {$[217]$} \\
PHB/Cellulose acetate butyrate & {$[218]$} \\
PLA/Poly(epichlorohydrin-co-ethylene oxide) (PEEO) & {$[219]$} \\
Poly(propylene carbonate)/Poly(ethylene-co-vinyl alcohol) & {$[220][221]$} \\
Chitosan/Soy protein & {$[222]$} \\
Chitosan/PLA & {$[223]$} \\
Pectin/PVOH & {$[224][225]$} \\
Cellulose/PVOH & {$[227]$} \\
\hline
\end{tabular}

PBS: Poly(3-hydroxybutyrate); PVOH: Polyvinyl alcohol.

be conveniently adjusted with the proper selection of the components and their concentration, processing techniques, etc. Hydrogels must also be mentioned. These are insoluble, highly swellable hydrophilic polymeric systems used as selective membranes [237], scaffolds [238] and drug-delivery systems [239]. Due to their high water content, they are very soft materials with viscoelastic properties similar to that of the living tissue [240] and they can be fabricated to be flexible, durable, and permeable to metabolites. The characteristics of hydrogels are determined by the type of the polymer, crosslinkage density, chain length and the degree of swelling [238].

\section{Incorporation of Fillers and Reinforcements (Biosourced Nanocomposites)}

The utility of nanoparticles as fillers and reinforcements to enhance the polymer performance is now well established. The most currently studied and developed are nanoclay (layered silicates), kaolinite, cellulose nanowhiskers, (CNC), ultra-fine layered titanate and carbon nanotubes.

Today, nanocomposites based on biodegradable polymers as matrix have clearly stimulated researches in this area. One of the most attractive is starch, owing to its complete biodegradability, wide availability, low cost and properties.

Table 7 summarizes the main nanocomposites which have been prepared and characterized using various biosourced polymers. 
Table 7. Examples of biosourced nanocomposites.

\begin{tabular}{|c|c|c|c|}
\hline \multicolumn{2}{|c|}{ Components } & \multirow{2}{*}{ Targeted property } & \multirow{2}{*}{ Reference } \\
\hline Matrix & Filler & & \\
\hline Starch & Clay & $\begin{array}{l}\text { Elongation at break, tensile strength, } \\
\text { water vapor transmission rate }\end{array}$ & [241] [242] \\
\hline Starch & MineralClay & Tensile strength, elongation & [243] \\
\hline Starch & MMT & High mechanical performance & {$[244]$} \\
\hline Starch & MMT & Tensile strength and strain & [245] \\
\hline Starch & Nanoclay & Structure and mechanical properties & [246] \\
\hline Starch & MMT & Thermal stability and water absorbance & [246] \\
\hline Starch/polyester & Organoclay & $\begin{array}{l}\text { Tensile strength, Young's modulus, } \\
\text { strain at break }\end{array}$ & [247] \\
\hline Starch/PCL & Organoclay & Elongation & [248] \\
\hline $\begin{array}{c}\text { Cellulose Ac. } \\
(+ \text { TEC: plasticizer })\end{array}$ & Clay & $\begin{array}{l}\text { Tensile strength, Young's modulus, heat } \\
\text { deflection temperature, water vapor } \\
\text { permeability and impact strength }\end{array}$ & [249] \\
\hline $\begin{array}{l}\text { Cellulose-Ac. } \\
(+C A B-g-M A: \\
\text { compatibilizer })\end{array}$ & Organoclay & Exfoliated structure & [249] \\
\hline$P L A$ & $\mathrm{CNC}$ & Mechanical properties & {$[250]$} \\
\hline $\begin{array}{l}P L A(+P V A: \\
\text { compatibilizer })\end{array}$ & $\mathrm{CNC}$ & Dispersion of $\mathrm{CNC}$ & [251] \\
\hline $\begin{array}{l}\text { LDPE }(+ \text { organic acid } \\
\text { chlorides: surface } \\
\text { modifiers })\end{array}$ & $\mathrm{CNC}$ & Elongation at break & [252] \\
\hline $\begin{array}{c}P E T / L D P E \\
(+I P N \text { compatibilizer })\end{array}$ & $\mathrm{CNC}$ & Mechanical properties & [253] \\
\hline PLA & Organoclay & Thermal and mechanical properties & [254] \\
\hline PLA & Layered silicates & $\begin{array}{l}\text { Effects of dispersion, intercalation, and aspect } \\
\text { ratio of the clay on the material properties. }\end{array}$ & [255] \\
\hline$P L A / P C L$ & Modified kaolinite & $\begin{array}{l}\text { Processability, thermal stability and } \\
\text { mechanical properties }\end{array}$ & [256] \\
\hline
\end{tabular}

Cellulose-Ac.: Cellulose acetate; TEC: Triethyl citrate; CAB-g-MA: maleic anhydride grafted cellulose acetobutyrate; PP: Polypropylene; CNC: Crystalline nanocellulose; PVA: Polyvinyl alcohol; LDPE: Low density poly(ethylene); IPN: Interpenetrated Network.

It is noteworthy to outline current attempts made to use cellulose nanocristals (CNC) as reinforcing agents for the production of nanocomposites, typically at their melt state, e.g. by melt extrusion.

In such case, the main problem to solve is related to the homogeneous dispersion of 
these hydrophylic nanoparticles within polymeric matrices which are generally hydrophobic.

To overcome this problem several chemical modifications of CNC surface have been developed allowing to use them for applications such as coating, adhesives, sealings, filters, membranes, packing and cosmetics, paper or board for printing etc. [9] [75].

\section{Conclusions and Future Prospects}

"A sizeable concrete enterprise,"

"Largely regulatory driven related businesses,"

"Largest Cellulosic Ethanol Plant in the World Opens October 30", reported by ENERGY.GOV, the Office of Energy Efficiency \& Renewable Energy on October 26, 2015, 2:52 $\mathrm{pm}^{*}$ ); as stated by the U.S. Department of Energy (DOE) Bioenergy Technologies Office (BETO).

This may be one of the most optimistic and illustrative conclusions of that review.

"With a Collaboratory ${ }^{T M}$ mindset"

Furthermore, "Through a partnership between Proctor and Gamble and DuPont, some of the cellulosic ethanol from this plant will be used in a laundry detergent." underlines the announcement. The facility is expected to produce about 30 million gallons of cellulosic ethanol per year. $\left(^{*}\right)$

(https://web.archive.org/web/*/http://energy.gov/eere/bioenergy/articles/largest-cellulo sic-ethanol-plant-world-opens-october-30

http://www.delawareonline.com/story/money/business/2014/10/06/dupont-pg-bring-ce llulosic-ethanol-tide-detergent/16842175/

http://www.25x25.org/index.php?option=com_content\&task=view\&id=1317\&Itemid= 246)

"Let's Bigger Data take part,"

"With the help of:"

"The IP analytics, the IP Technology and Innovation Strategist."

Pursuing with the approach of innovation via Bigger Data analysis, Figure 11(a) and Figure 11(b) (close-ups of Zones A, B, C of Figure 11(a)) portray the use of IP analytics to underline science and technology diversity that lies with this type of innovation. The illustrative patent (US20070031953A1, US799871) was filed in 2005 (red arrow on the figure) and got granted in 2011 after being published in 2007 (red right vertical axle with yellow arrow). The analytics represented on this figure was performed with the Approach G and comprised among others the following information: the CPC (cooperative patent classification) classes on the left vertical axis, as a function of time, represented on the horizontal axis, the various patents that were cited to support the patent application as well as the patents citing the considered patent after its publication in 2007 (each citation was represented by a graphical symbol inside the graphic axes). Citing and cited organizations are listed below the main graph of Figure 11(a) and partially zoomed in Figure 11(b).

"Multi-science founded and still today biotechnology, via 'Biosourced, requires an upfront pioneering state of mind." 


\section{Forward \& Backward Citations US20070031953: Treatment of biomass to obtain ethanol}

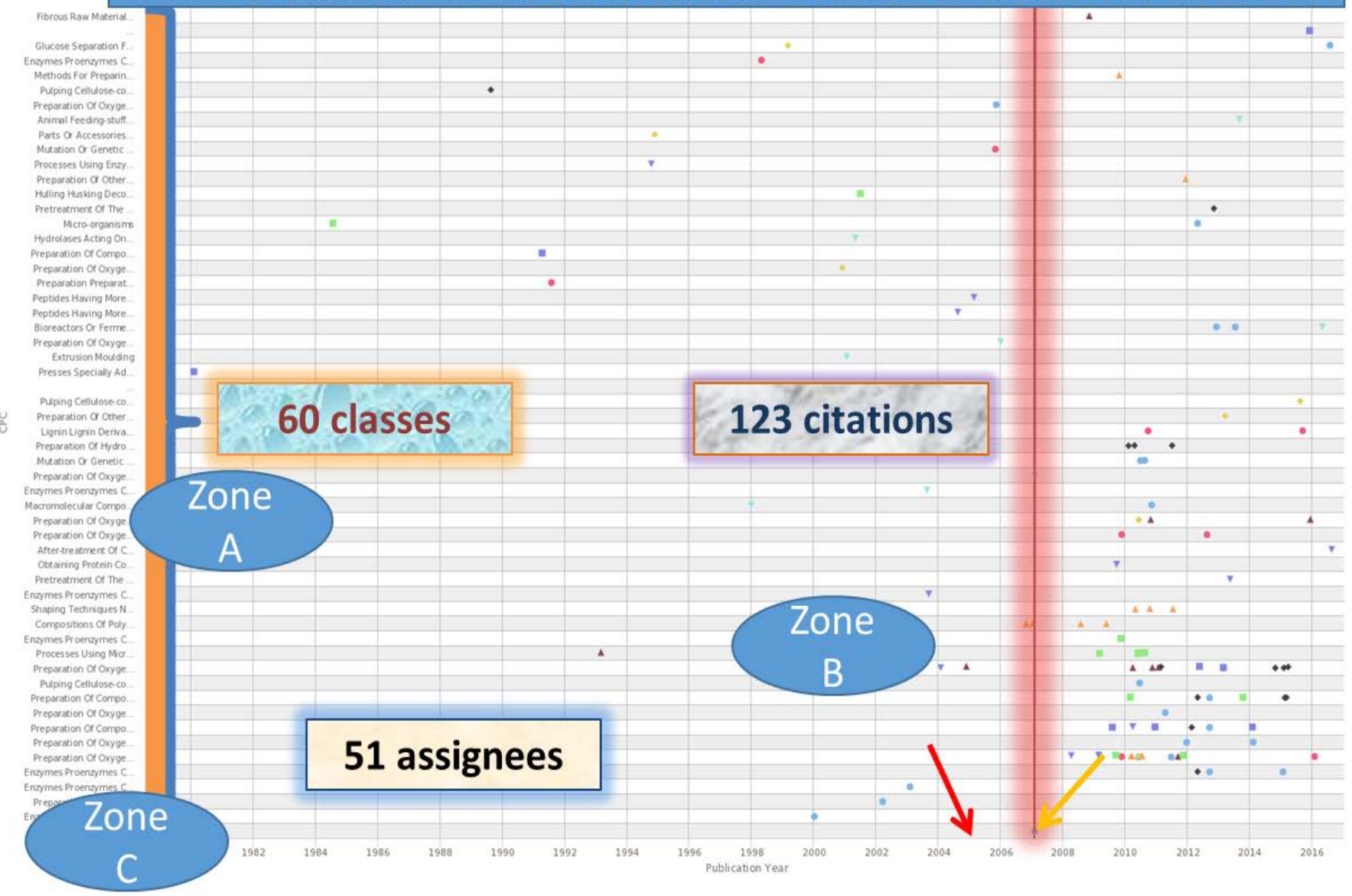

\section{Organizations}

[15] E.i. Du Pont De Nemours \& Company

- [4] Jj Florida Properties Llc

- [3] Mascoma Corporation

- [2] Nippon Steel and Sumikin Chemical Co., Ltd., Jp

- [2] Aikan Corporation

- [1] Colorado State University

- 11] Lallemand Hungary Liquidity Management LIc

- [1] Ajinomoto Co., Inc.

- [1] State University System of Florida

- [1] Agriculture United States of America the as Represented by the Secretary

- [1] Virida, Inc.
[8] Codexis Inc Biofuels LIC

- [3] Brijen Biotech, Llc

[2] Virdia Inc.

- [2] Ultrasound Brewery

- [1] Uchicago Argonne LIc
[4] Butamax Advanced

- [8] University of Massachusetts $\wedge$ [7] Xyleco Inc

- [4] Syngenta Ag

[3] Edeniq, Inc.

- [2] Satake Corporation

[2] Lallemand, Inc.

- [1] Ruhrchemie Aktiengesellschaft A Corp

[1] Nederlandse Organisatie [1] University of Illinois Voor Toegepastnatuurwetenschappelijk Onderzoed Tno

[1] Burford Garden Centre Ltd. " [1] Poet Llc

$\bullet$ [1] Sunopta, Inc.

[1] logen Energy Corp

[1] Dedini Saadministracao E a [1] Enchi Corporation

Participacoes

[4] Qteros, Inc.

[3] Omnilytics Inc.

^ [2] Reliance Life Sciences Pvt Ltd

$\triangle$ [2] logen Corporation

- [1] Michigan Biotechnology Institute 3900 Collins Road Po Box 27609 Lansing Michigan 48909 a Michigan Not-profit Crop

$\triangle$ [1] Lali, Arvind

A [1] Bayer Ag

$\Delta[1] \mathrm{lcm}, \mathrm{Inc}$

A [1] Andritz Ag $\nabla$ [5] Unassigned

v [4] Sustainable Energy Technologies Ltd.

v [3] Rowan Companies. Inc.

$\checkmark$ [2] Michigan State University

v [2] Novo Nordisk Fonden

$\checkmark$ [1] Novozymes A/S

-11] Daicel Corporation
$\checkmark$ [1] Commonwealth Scientific \& Industrial Research Organisation
$\checkmark$ [1] Basf $\mathrm{Se}$
$\nabla$ [1] Aikan North America, Inc.




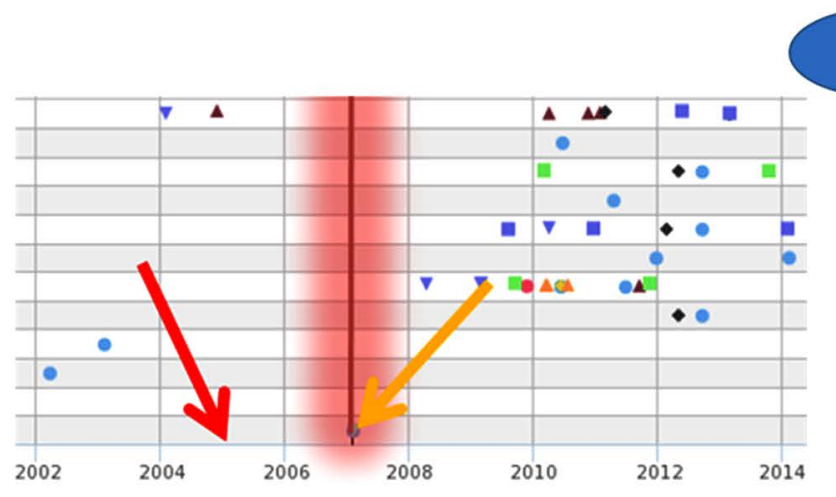

\section{Zone}

\section{Organizations}

- [15] E.i. Du Pont De Nemours \& Company

- [4] Jj Florida Properties LIC

\section{- [8] Codexis Inc}

- [4] Butamax Advanced Biofuels Llc
- [8] University of Massachusetts

- [4] Sungenta $\mathrm{Ag}$

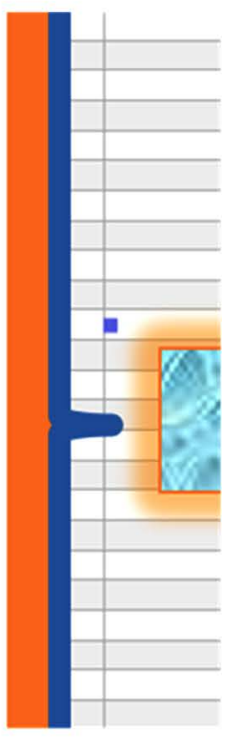

$\Delta$ [7] Xyleco Inc

- [4] Qteros, Inc.

(b)

Figure 11. (a) An illustration of the diverse and inspiring background associated with a patent in the field of Interest- "Biosourced": “Treatment of Biomass to obtain Ethanol”-US799871-US20070031953 applied by DuPont ${ }^{\mathrm{TM}}$ DE(US) and Alliance for Sustainable Energy LLC CO(US). (b) Close-ups of Zones A, B, C of Figure 11(a).

Remaining at educational level, the particular patent analysis demonstrated that 50 60 classes (chemical, biological, botanical, physical, enzymes, microorganisms, engineering, genetics, digital, polymer technology, etc.) were associated with it. 50 "related" assignees for 120 citations were found. More than 75 non-patent literature references (NPL) are cited in the published granted patent document. Such metrics are far above average in the patent field.

These dimensions prove the challenges and opportunities associated with "Biosourced". The knowledge and humanity development magnitude is central.

No wonder that this review required the examination and treatment of a large amount of data and references, more than 250 cited references, 10,000 patent documents were processed, etc.

In short, after setting the ground of the quantum innovation potential of biosourced entities and outlining the inventive spectrum of adjacent technologies that can derive from those, the current review also outlines, with the support of Bigger Data approaches, the following: an overview of biosourced chemicals and materials, mainly biomonomers, biooligomers and biopolymers, which are produced today allowing to reduce the fossil resources depletion and dependency, and to obtain environmentally-friendlier goods in a leaner energy consuming society. 
"Leaner, faster, simpler" - with the same high quality, high safety standards and appropriate functionality - is the slogan for the "Frugal" awaited mode of innovation.

Although providing a large reference database, this review remains largely initiatory, therefore not mimicking previous classic reviews but putting them in a multiplying synergistic prospective.

"Other challenges ahead: the processing dimension, the sustainability, the local sourcing... Frugal innovation may help... the last mile counts..."

The processing dimension will remain evolutionary and likely "revolutionary".

Operational and rather productive methodology is able to generate 1) directly, specific biosourced polymers and 2) biomonomers and precusors for further polymerization. The direct production of biosourced polymers enhances the productivity and the tailoring of the composition and the properties of poly- and oligo-saccharides and poly(hydroxyalkanoates) (PHAs), for example.

From a regulatory prospective the direct and indirect approaches 1) and 2) above, tend to be classified separately. This can sometime create a challenging value chain consolidation situation.

Regarding product and ingredient an increasing number of biomonomer buildingblocks such as lactic acid, succinic acid, hydroxyacids, diols and polyamide and styrenic vinyls monomers are also produced. These are used to manufacture important biosourced advanced polymers (e.g., linear and aromatic polyesters, polyamides and styrenic vinyls polymers) which are now able to replace totally or partially the polymers currently originating from fossil resources.

Harvesting the benefits of "biosourced" has some rather universally encountered challenges associated with it, such as the removal of water which is closely connected with the upstream and downstream processes [257].

Other challenges are cost $\&$ affordability, as well as sustainability \& local sourcing.

It is worth mentioning to that affect, that for example the carbon-based structures, including hybrids, are currently evolving considerably with a lower cost spectrum, integrated sustainability criteria, a holistic value chain and a rethought manufacturing pattern, such as the cell and modular concepts [258].

Hopefully this review and the above future prospects and challenges will serve as a solid "starting" point and will provide educational creative inspiration therewith.

\section{Acknowledgements}

The authors thank: Benoît Steffenino for part of the illustrations and the artistic codesign with authors.

\section{More about the Authors}

Serge Rebouillat [Phonetically: Rebooya], Dr. Ing., Dr-ès-Sciences, Certified Prof., Ind. Energetic, Chem/Bio Eng., Rheology, IP: Mediation/Innovation \& Strategy/Mana- gement/Valuation. Fernand Pla, Dr. Ing., Dr-ès-Sciences Physiques, full Professor at the University of Lorraine (Nancy, France), Head of a research group working in Polymer 
Reaction Engineering.

\section{Disclaimer}

This article is primarily for educational purposes. Selected cases are strictly illustrative. Neither the author nor the illustrator assumes any liability for any errors or oversights, for how this article or its contents are utilized or interpreted or for any consequences resulting directly or indirectly from the usage of it.

This information is for general knowledge. For critical applications, requirements should be checked with the suppliers. For additional guidance, legal or any other, seek advice from the appropriate qualified professionals; this study can by no means substitute for legal, technical and managerial expert advice.

The opinions expressed by the writers in this article do not necessarily represent the viewpoints of the company one of the authors is employed by.

\section{References}

[1] WIPO (2016).

http://www.wipo.int/patentscope/en/programs/patent_landscapes/reports/microalgae.html

[2] Rebouillat, S. (2013) A Science \& Business Equation for Collaborative Corporate Innovation. Business Strategy, IP Strategy, R\&D Strategy: An All-in-One Business Model. A Review with a Bio-Technology \& Green Chemistry Focus. International Journal of Innovation and Applied Studies, 4, 1-19.

[3] Rebouillat, S. and Lapray, M. (2014) Bio-Inspired and Bio-Inspiration: A Disruptive Innovation Opportunity or a Matter of "Semantic"? A Review of a "Stronger than Logic" Creative Path Based on Curiosity and Confidence. International Journal of Innovation and Applied Studies, 6, 299-325.

[4] Lapray, D. and Rebouillat, S. (2014) "Bigger Data" Visualization to Visual Analytics: A Path to Innovation. "Happening, Definitely! Misleading, Possibly?" A Review of Some Examples Applicable to IP Discovery. International Journal of Innovation and Applied Studies, 7, 1251-1273).

[5] Rebouillat, S. (2016) Aramids: "Disruptive", Open and Continuous Innovation. In: Chen, X., Ed., Advanced Fibrous Composite Materials for Ballistic Protection, Woodhead Publishing Limited, Amsterdam, Boston, Cambridge, Heidelberg, London, New York, Oxford, Paris, San Diego, San Francisco, Singapore, Sydney and Tokyo, 11-70. http://dx.doi.org/10.1016/b978-1-78242-461-1.00002-9

[6] Rebouillat, S. and Knowlton, S. (2009) Dielectric Heat-Transfer Fluid. CA2754291A1; CN102365343A; EP2411481A2; US9185826; US20140036447; WO2010111698A2.

[7] Rebouillat, S., Thoonen G.F., Rochette, F. and Steffenino, B. (2011) Liquid Compositions Used as Insulating and Heat Transfer Means, Electrical Devices Containing Said Compositions and Preparation Methods for Such Compositions. CN103988266A; EP2764520A2; US20130099182; WO2013052956A3.

[8] Rebouillat, S., Olesen, J. and Pfister, F. (1998-2003) Fiber Used in a Fiber Optic CableCoated with a Water Blocking Material that Includes Polygalactomannan. EP0985066B1; WO0031752; EP1133774B9; US6891003.

[9] Rebouillat, S. and Pla, F. (2013) State of the Art Manufacturing and Engineering of Nanocellulose: A Review of Available Data and Industrial Applications. Journal of Biomaterials 
and Nanobiotechnology, 4,165-188. http://dx.doi.org/10.4236/jbnb.2013.42022

[10] Rebouillat, S. and Ortega-Requena, S. (2015) Potential Applications of Milk Fractions and Valorization of Dairy By-Products: A Review of the State-of-the-Art Available Data, Outlining the Innovation Potential from a Bigger Data Standpoint. Journal of Biomaterials and Nanobiotechnology, 6, 176-203. http://dx.doi.org/10.4236/jbnb.2015.63018

[11] Lapray, M. and Rebouillat, S. (2014) Innovation Review: Closed, Open, Collaborative, Disruptive, Inclusive, Nested... and Soon Reverse. How About the Metrics: Dream and Reality. International Journal of Innovation and Applied Studies, 9, 1-28.

[12] Rebouillat, S. and Lapray, D. (2014) A Review Assessing the "Used in the Art" Intellectual Property Search Methods and the Innovation Impact therewith. International Journal of Innovation and Applied Studies, 5, 160-191.

[13] Morris, D.J. and Ahmed, I. (1992) The Carbohydrate Economy: Making Chemicals and Industrial Materials from Plant Matter. Institute of Local Self Reliance, Washington DC.

[14] Carole, T.M., Pellegrino, J. and Paster, M.D. (2004) Opportunities in the Industrial Biobased Products Industry. Applied Biochemistry Biotechnology, 115, 871-885.

http://dx.doi.org/10.1385/ABAB:115:1-3:0871

[15] Archambault, E., Bertrand, F., Côté, G., Craig-Dupont, O., Larivière V. and Gagné, É.V. (2004) Towards a Canadian R\&D Strategy for Bioproducts and Bioprocesses. National Research Council of Canada. http://www.science-metrix.com/pdf/SM_2003_014_NRC_Canadian_R\&D_Strategy.pdf

[16] Hüsing, B., Angerer, G., Gaisser, F. and Marscheider-Weidemann, F. (2003) Biotechnological Production of Value-Added Substances from Industrial Waste Streams with Special Reference to Energy Carriers and Biopolymers. Ber.-Umweltbundesamt (Ger).

[17] Paster, M.D., Pellegrino, J. and Carole, T.M. (2003) Industrial Bioproducts: Today and Tomorrow. Office of the Biomass Program, Office of Energy Efficiency and Renewable Energy, US Department of Energy, Washington DC.

[18] Patel, M., Crank, M., Dornburg, V., Hermann, B., Hüsing, B., Overbeek, L., Terragni, F. and Recchia, E. (2006) Medium and Long-Term Opportunities and Risks of the Biotechnological Production of Bulk Chemicals from Renewable Resources-The Potential of White Biotechnology: The Brew Project. European Commission's GROWTH Programme (DG Research), Utrecht. http://www.chem.uu.nl/brew/

[19] Werpy, T.A. and Petersen, G., Eds. (2004) Top Value Added Chemicals from Biomass. Volume I: Results of Screening for Potential Candidates from Sugars and Synthesis Gas. Pacific Northwest National Laboratory (PNNL) and National Renewable Energy Laboratory (NREL). http://www.osti.gov/bridge

[20] Crank, M., Patel, M., Marscheider-Weidemann, F., Schleich, J., Hüsing, B. and Angerer, G. (2004) Techno-Economic Feasibility of Large-Scale Production of Bio-Based Polymers in Europe (Pro-BIP). European Commissions' Institute for Prospective Technological Studies (IPTS), Sevilla.

[21] Jarboe, L.R., Zhang, X., Wang, X., Moore, J.C., Shanmugam, K.T. and Ingram, L.O. (2010) Metabolic Engineering for Production of Biorenewable Fuels and Chemicals: Contributions of Synthetic Biology. Journal of Biomedicine and Biotechnology, 2010, Article ID: 761042. http://dx.doi.org/10.1155/2010/761042

[22] Lee, S.K., Howard, C., Ham, T.S., Lee, T.S. and Keasling, J.D. (2008) Metabolic Engineering of Microorganisms for Biofuels Production: From Bugs to Synthetic Biology to Fuels. Current Opinion in Biotechnology, 19, 556-563. http://dx.doi.org/10.1016/j.copbio.2008.10.014

[23] Park, J.H., Lee, S.Y., Kim, T.Y. and Kim, H.U. (2008) Application of Systems Biology for 
Bioprocess Development. Trends Biotechnology, 26, 404-412.

http://dx.doi.org/10.1016/j.tibtech.2008.05.001

[24] Mainguet, S.E. and Liao, J.C. (2010) Bioengineering of Microorganisms for C3 to C5 Alcohols Production. Biotechnology Journal, 5, 1297-1308.

http://dx.doi.org/10.1002/biot.201000276

[25] Blazeck, J. and Alper, H. (2010) Systems Metabolic Engineering: Genome-Scale Models and Beyond. Biotechnology Journal, 5, 647-659. http://dx.doi.org/10.1002/biot.200900247

[26] Committee on Biobased Industrial Products (2000) Biobased Industrial Products: Research and Commercialization Priorities. National Research Council. National Academy Press Washington DC, 162 p. http://www.nap.edu/catalog/5295.html

[27] Becker, J., Zelder, O., Hafner, S., Schroder, H. and Wittmann, C. (2011) From Zero to Hero-Design-Based Systems Metabolic Engineering of Corynebacterium Glutamicum for L-Lysine Production. Metabolic Engineering, 13, 159-168. http://dx.doi.org/10.1016/j.ymben.2011.01.003

[28] Lee, J.W., Kim, T.Y., Jang, Y.S., Choi, S. and Lee, S.Y. (2011) Systems Metabolic Engineering for Chemicals and Materials. Trends in Biotechnology, 29, 370-378. http://dx.doi.org/10.1016/j.tibtech.2011.04.001

[29] Lee, J.W., Na, D., Park, J.M., Lee, J., Choi, S. and Lee, S.Y. (2012) Systems Metabolic Engineering of Microorganisms for Natural and Non-Natural Chemicals. Nature Chemical Biology, 8, 536-546. http://dx.doi.org/10.1038/nchembio.970

[30] Cho, C., Choi, S.Y., Luo, Z.W. and Lee, S. Y. (2015) Recent Advances in Microbial Production of Fuels and Chemicals Using Tools and Strategies of Systems Metabolic Engineering. Biotechnology Advances, 33, 1455-1466. http://dx.doi.org/10.1016/j.biotechadv.2014.11.006

[31] Jang, Y.S., Lee, J.Y., Lee, J., Park, J.H., Im, J.A., Eom, M.H., Lee, J., Lee, S.H., Song, H., Cho, J.H., Seung, D.Y. and Lee, S.Y. (2012) Enhanced Butanol Production Obtained by Reinforcing the Direct Butanol-Forming Route in Clostridium Acetobutylicum. mBio, 3, e00314-12. http://dx.doi.org/10.1128/mbio.00314-12

[32] Atsumi, S., Hanai, T. and Liao, J.C. (2008) Non-Fermentative Pathways for Synthesis of Branched-Chain Higher Alcohols as Biofuels. Nature, 451, 86-89.

http://dx.doi.org/10.1038/nature06450

[33] Shen, C.R., Lan, E.I., Dekishima, Y., Baez, A., Cho, K.M. and Liao, J.C (2011) Driving Forces Enable High-Titer Anaerobic 1-Butanol Synthesis in Escherichia Coli. Applied and Environmental Microbiology, 77, 2905-2915. http://dx.doi.org/10.1128/AEM.03034-10

[34] Na, D., Yoo, S.M., Chung, H., Park, H., Park, J.H. and Lee, S.Y. (2013) Metabolic Engineering of Escherichia Coli Using Synthetic Small Regulatory RNAs. Nature Biotechnology, 31, 170-174. http://dx.doi.org/10.1038/nbt.2461

[35] Yoo, S.M., Na, D. and Lee, S.Y. (2013) Design and Use of Synthetic Regulatory Small RNAS to Control Gene Expression in Escherichia coli. Nature Biotechnology, 8, 1694-1707. http://dx.doi.org/10.1038/nprot.2013.105

[36] Flowers, D., Thompson, R.A., Birdwell, D., Wang, T. and Trinh, C.T. (2013) SMET: Systematic Multiple Enzyme Targeting-A Method to Rationally Design Optimal Strains for Target Chemical Overproduction. Biotechnology Journal, 8, 605-618. http://dx.doi.org/10.1002/biot.201200233

[37] Isaacs, F.J., Carr, P.A., Wang, H.H., Lajoie, M.J., Sterling, B., Kraal, L., Tolonen, A.C., Gianoulis, T.A., Goodman, D.B., Reppas, N.B., Emig, C.J., Bang, D., Hwang, S.J., Jewett, M.C., Jacobson, J.M. and Church, G.M. (2011) Precise Manipulation of Chromosomes in Vivo Enables Genome-Wide Codon Replacement. Science, 333, 348-353. 
http://dx.doi.org/10.1126/science.1205822

[38] Wang, H.H., Isaacs, F.J., Carr, P.A., Sun, Z.Z., Xu, G., Forest, C.R. and Church, G.M. (2009) Programming Cells by Multiplex Genome Engineering and Accelerated Evolution. Nature, 460, 894-898. http://dx.doi.org/10.1038/nature08187

[39] Thieffry, D. (2007) Dynamical Roles of Biological Regulatory Circuits. Briefings in Bioinformatics, 8, 220-255. http://dx.doi.org/10.1093/bib/bbm028

[40] Park, J.H., Lee, K.H., Kim, T.Y. and Lee, S.Y. (2007) Metabolic Engineering of Escherichia Coli for the Production of L-Valine Based on Transcriptome Analysis and in Silico Gene Knockout Simulation. Proceedings of the National Academy of Sciences of the United States of America, 104, 7797-7802. http://dx.doi.org/10.1073/pnas.0702609104

[41] Yim, H., Haselbeck, R., Niu, W., Pujol-Baxley, C., Burgard, A., Boldt, J., Khandurina, J., Trawick, J.D., Osterhout, R.E., Stephen, R., Estadilla, J., Teisan, S., Schreyer, H.B., Andrae, S., Yang, T.H., Lee, S.Y., Burk, M.J. and Van Dien, S. (2011) Metabolic Engineering of Escherichia coli for Direct Production of 1,4-Butanediol. Nature Chemical Biology, 7, 445452. http://dx.doi.org/10.1038/nchembio.580

[42] Park, J.H., Kim, T.Y., Lee, K.H. and Lee, S.Y. (2011) Fed-Batch Culture of Escherichia coli for L-Valine Production Based on in Silico Flux Response Analysis. Biotechnology and Bioengineering, 108, 934-946. http://dx.doi.org/10.1002/bit.22995

[43] Song, H., Kim, T.Y., Choi, B.K., Choi, S.J., Nielsen, L.K., Chang, H.N. and Lee, S.Y. (2008) Development of Chemically Defined Medium for Mannheimia succiniciproducens Based on Its Genome Sequence. Applied Microbiology and Biotechnology, 79, 263-272. http://dx.doi.org/10.1007/s00253-008-1425-2

[44] Thompson, R.A. and Trinh, C.T. (2014) Enhancing Fatty Acid Ethyl Ester Production in Saccharomyces cerevisiae through Metabolic Engineering and Medium Optimization. Biotechnology and Bioengineering, 111, 2200-2208. http://dx.doi.org/10.1002/bit.25292

[45] Causey, T.B., Zhou, S., Shanmugam, K.T. and Ingram, L.O. (2003) Engineering the Metabolism of Escherichia coli W3110 for the Conversion of Sugar to Redox-Neutral and Oxidized Products: Homoacetate Production. Proceedings of the National Academy of Sciences of the United States of America, 100, 825-832. http://dx.doi.org/10.1073/pnas.0337684100

[46] Zhu, Y., Eiteman, M.A., DeWitt, K. and Altman, E. (2007) Homolactate Fermentation by Metabolically Engineered Escherichia coli Strains. Applied and Environmental Microbiology, 73, 456-464. http://dx.doi.org/10.1128/AEM.02022-06

[47] Pillai, C.K.S. (2010) Challenges for Monomers and Polymers: Novel Design Strategies and Engineering to Develop Advanced Polymers. Designed Monomers and Polymers, 13, 87121. http://dx.doi.org/10.1163/138577210X12634696333190

[48] Erickson, B., Nelson, J.E. and Winters, P. (2011) Perspective on Opportunities in Industrial Biotechnology in Renewable Chemicals. Biotechnology Journal, 7, 76-185.

[49] Adkins, J., Pugh, S., McKenna, R. and Nielsen, D.R. (2012) Engineering Microbial Chemical Factories to Produce Renewable Biomonomers. Frontiers in Microbiology, 3, 313. http://dx.doi.org/10.3389/fmicb.2012.00313

[50] Lee, J.W., Kim, H.U., Choi, S., Yi, J. and Lee, S.Y. (2011) Microbial Production of Building Block Chemicals and Polymers. Current Opinion in Biotechnology, 22, 758-767. http://dx.doi.org/10.1016/j.copbio.2011.02.011

[51] Curran, K.A. and Alper, H.S. (2012) Expanding the Chemical Palate of Cells by Combining Systems Biology and Metabolic Engineering. Metabolic Engineering, 14, 289-297. http://dx.doi.org/10.1016/j.ymben.2012.04.006

[52] Polman, K. (1994) Review and Analysis of Renewable Feed Stocks for the Production of 
Commodity Chemicals. Applied Biochemistry and Biotechnology, 45, 709-722.

http://dx.doi.org/10.1007/BF02941842

[53] Sudesh, K. and Iwata, T. (2008) Sustainability of Biobased and Biodegradable Plastics. CLEAN-Soil Air Water, 36, 433-442. http://dx.doi.org/10.1002/clen.200700183

[54] Mohanty, A.K., Misra, M. and Hinrichsen, G. (2000) Biofibres, Biodegradable Polymers and Biocomposites: An Overview. Macromolecular Materials and Engineering, 1, 276-277. http://dx.doi.org/10.1002/(sici)1439-2054(20000301)276:1<1::aid-mame1>3.0.co;2-w

[55] European Bioplastics Driving the Evolution of Plastics (2012). http://www.european-bioplastics.org/bioplastics

[56] Shen, K., Haufe, J. and Patel, M.K. (2009) Product Overview and Market Projection of Emerging Bio-Based Plastics. Final Report of Utrecht University to European Bioplastics.

[57] Brunow, G. (2001) Methods to Reveal the Structure of Lignin. In: Hofrichter, M. and Steinbüchel, A., Eds., Biopolymers. Lignin, Humic Substances and Coal, Vol. 1, WileyVCH, Weinheim, 89-116.

[58] Mohamad Ibrahim, M.N., Azian, H. and Mohd Yusop, M.R. (2006) Separation and Characterization of the Vanillin Compound from Soda Lignin. Journal Technology, 44, 83-94.

[59] Jonsson, A.S., Nordin, A.K. and Wallberg, O. (2008) Concentration and Purification of Lignin in Hardwood Kraft Pulping Liquor by Ultrafiltration and Nanofiltration. Chemical Engineering Research and Design, 86, 1271-1280. http://dx.doi.org/10.1016/j.cherd.2008.06.003

[60] Roberts, V.M., Stein, V., Reiner, T., Lemonidou, A., Li, X. and Lercher, J.A. (2011) Towards Quantitative Catalytic Lignin Depolymerization. Chemistry-A European Journal, 17, 5939- 5948. http://dx.doi.org/10.1002/chem.201002438

[61] Li, J., Henriksson, G. and Gellerstedt, G. (2007) Lignin Depolymerization/Repolymerization and Its Critical Role for Delignification of Aspen Wood by Steam Explosion. Bioresource Technology, 98, 3061-3068. http://dx.doi.org/10.1016/j.biortech.2006.10.018

[62] Pandey, M.P. and Kim, C.S. (2011) Lignin Depolymerization and Conversion: A Review of Thermochemical Methods. Chemical Engineering \& Technology, 34, 29-41. http://dx.doi.org/10.1002/ceat.201000270

[63] Stewart, D. (2008) Transesterification of Epoxidized Soybean Oil to Prepare Epoxy Methyl Esters. Industrial Crops and Products, 27, 202-207. http://dx.doi.org/10.1016/j.indcrop.2007.07.008

[64] Babu, R.P., O’Connor, K. and Seeram, R. (2013) Current Progress on Bio-Based Polymers and Their Future Trends. Progress in Biomaterials, 2, 1-16.

http://dx.doi.org/10.1186/2194-0517-2-8

[65] Klemm, D., Heublein, B., Fink, H.P. and Bohn, A. (2005) Cellulose: Fascinating Biopolymer and Sustainable Raw Material. Angewandte Chemie International Edition, 44, 3358-3393. http://dx.doi.org/10.1002/anie.200460587

[66] Simon, J., Müller, H.P., Koch, R. and Müller, V. (1998) Thermoplastic and Biodegradable Polymers of Cellulose. Polymer Degradation and Stability, 59, 107-115. http://dx.doi.org/10.1016/S0141-3910(97)00151-1

[67] Wang, Z.-F., Fang, L., Zhang, K.-X. and Fu, X. (2008) Application and Research Progress of Starch in Polymer Materials. Journal for Clinical Rehabilitation Tissue Engineering Research, 19, 3789-3792.

[68] Kalambur, S. and Rizvi, S.S.H. (2006) An Overview of Starch Based Plastic Blends From Reactive Extrusion. Journal of Plastic Film \& Sheeting, 22, 39-58. 
http://dx.doi.org/10.1177/8756087906062729

[69] Pillai, C.K.S., Willi, P. and Sharma, C.P. (2009) Chitin and Chitosan Polymers: Chemistry, Solubility and Fiber Formation. Progress in Polymer Science, 34, 641-678.

http://dx.doi.org/10.1016/j.progpolymsci.2009.04.001

[70] Hearle, J.W.S. (2007) Protein Fibers: Structural Mechanics and Future Opportunities. Journal of Materials Science, 42, 8010-8019. http://dx.doi.org/10.1016/j.progpolymsci.2009.04.001

[71] Poole, A.J., Church, J.S. and Huson, M.G. (2008) Environmentally Sustainable Fibers from Regenerated Protein. Biomacromolecules, 10, 1-8. http://dx.doi.org/10.1021/bm8010648

[72] Heino, J., Huhtala, M., Käpylä, J. and Johnson, M.S. (2009) Evolution of collagen-Based Adhesion Systems. International Journal of Biochemistry \& Cell Biology, 41, 341-348. http://dx.doi.org/10.1016/j.biocel.2008.08.021

[73] Habibi, Y., Goffin, A.L., Schiltz, N., Duquesne, E., Dubois, P. and Dufresne, A. (2008) Bionanocomposites Based on Poly(Epsilon-Caprolactone)-Grafted Cellulose Nanocrystals by Ring-Opening Polymerization. Journal of Materials Science, 18, 5002-5010.

[74] Shatkin, J.A., Wegner, T.H., Bilek, E.M. and Cowie, J. (2014) Market Projections of Cellulose Nanomaterial-Enabled Products-Part 1: Applications. TAPPI Journal, 13, 9-16.

[75] Moon, R.J., Martini, A., Nairn, J., Simonsen, J. and Youngblood, J. (2011) Cellulose Nanomaterials Review: Structure, Properties and Nanocomposites. Chemical Society Reviews, 40, 3941-3994. http://dx.doi.org/10.1039/c0cs00108b

[76] Hafren, J. and Cordova, A. (2005) Direct Organocatalytic Polymerization from Cellulose Fibers. Macromolecular Rapid Communications, 26, 82-86.

http://dx.doi.org/10.1002/marc.200400470

[77] Lonnberg, H., Zhou, Q., Brumer, H., Teeri, T.T., Malmstrom, E. and Hult, A. (2006) Grafting of Cellulose Fibers With Poly(Epsilon-Caprolactone) and Poly(L-Lactic Acid) via RingOpening Polymerization. Biomacromolecules, 7, 2178-2185. http://dx.doi.org/10.1021/bm060178z

[78] Berezina, N., Nys, J. and Yada, B. (2013) Method for the Analysis of Grafted Cellulosic Materials. Chemical Engineering Transactions, 32, 1003-1008.

[79] Tester, R.F. and Karkalas, J. (2002) Starch. In: De Baets, S., Vandamme, E.J. and Steinbuchel, A., Eds., Biopolymers. Polysaccharides II, Wiley-VCH, Weinheim, 381-438.

[80] Lourdin, D., Coignard, L., Bizot, H. and Colonna, P. (1997) Influence of Equilibrium Relative Humidity and Plasticizer Concentration on the Water Content and Glass Transition of Starch Materials. Polymer, 38, 5401-5406.

http://dx.doi.org/10.1016/S0032-3861(97)00082-7

[81] Avella, M., de Vlieger, J.J., Enrico, M.E., Fischer, S., Vacca, P. and Volpe, M.G. (2005) Biodegradable Starch/Clay Nanocomposite Films for Food Packaging Applications. Food Chemistry, 93, 467-474. http://dx.doi.org/10.1016/j.foodchem.2004.10.024

[82] Averous, L., Fringant, C. and Moro, L. (2001) Starch-Based Biodegradable Materials Suitable for Thermoforming Packaging. Starch, 53, 368-371.

http://dx.doi.org/10.1002/1521-379X(200108)53:8<368::AID-STAR368>3.0.CO;2-W

[83] Bae, K.P. and Moo-Moo, K. (2010) Applications of Chitin and Its Derivatives in Biological Medicine. International Journal of Molecular Sciences, 11, 5152-5164. http://dx.doi.org/10.3390/ijms11125152

[84] Ramya, R., Venkatesan, J., Kim, S.K. and Sudha, P.N. (2012) Biomedical Applications of Chitosan: An Overview. Journal of Biomaterial Tissue Engineering, 2, 100-111. 
http://dx.doi.org/10.1166/jbt.2012.1030

[85] Rekha, M.R. and Chrndra, P.S. (2007) Pullulan as a Promising Biomaterial for Biomedical Applications: A Perspective. Trends in Biomaterials and Artificial Organs, 20, 21-45.

[86] Zajic, J.E. and LeDuy, A. (1973) Flocculant and Chemical Properties of a Polysaccharide from Pullularia pullulans. Applied Microbiology, 25, 628-635.

[87] Singh, R.S., Saini, G.K. and Kennedy, J.F. (2008) Pullulan: Microbial Sources, Production and Applications. Carbohydrate Polymers, 73, 515-531.

http://dx.doi.org/10.1016/j.carbpol.2008.01.003

[88] Cheng, K.C., Demirci, A. and Catchmark, J.M. (2011) Pullulan: Biosynthesis, Production, and Applications. Applied Microbiology and Biotechnology, 92, 29-44. http://dx.doi.org/10.1007/s00253-011-3477-y

[89] Pla, F. and Robert, A. (1984) Etude du Caractère Réticulé de la Lignine in Situ. Holzforschung, 38, 213-220. http://dx.doi.org/10.1515/hfsg.1984.38.4.213

[90] Yan, J.F., Pla, F., Kondo, R., Dolk, M. and Mc Carthy, J.L. (1984) Lignin XXI. Depolymerisation by Bond Cleavage Reactions and Degelation.Macromolecules, 17, 2137-2142. http://dx.doi.org/10.1021/ma00140a046

[91] Pla, F., Dolk, M., Yan, J.F. and Mc Carthy, J.L. (1985) Macromolecular Characteristics of Alkali and Organosolv Lignins from Black Cottonwood. Proceedings of the 3 rd International Symposium on Wood and Pulping Chemistry, Vancouver, 26-29 August 1985, 65-71.

[92] Pla, F. and Yan, J.F. (1984) Branching and Functionality of Lignin Molecules. Journal of Wood Chemistry and Technology, 4, 285-299. http://dx.doi.org/10.1080/02773818408070649

[93] Thakur, V.K., Thakur, M. K., Raghavan, P., and Kessler, M. R. (2014) Progress in Green Polymer Composites from Lignin for Multifunctional Applications: A Review. ACS Sustainable Chemical Engineering, 2, 1072-1092. http://dx.doi.org/10.1021/sc500087z

[94] Cheradame, H., Detoisien, M., Gandini, A., Roux G. and Pla, F. (1989) Polyurethane from Kraft Lignin. British Polymer Journal, 21, 269-275. http://dx.doi.org/10.1002/pi.4980210314

[95] Czaja, W., Krystynowicz, A., Bielecki, S. and Brown, R.M. (2006) Microbial Cellulose-The Natural Power to Heal Wounds. Biomaterials, 27, 145-151.

http://dx.doi.org/10.1016/j.biomaterials.2005.07.035

[96] Hoenich, N. (2006) Cellulose for Medical Applications: Past, Present, and Future. Bioresources, 1, 270-280.

[97] Berezina, N. and Martelli, S.M. (2014) Chapter 1: Bio-Based Polymers and Materials. In: Lin, C. and Luque, R., Eds., Renewable Resources for Biorefineries, Royal Society of Chemistry, Series: Green Chemistry, London, 1-28. http://dx.doi.org/10.1039/9781782620181-00001

[98] Reinecke, F. and Steinbuchel, A. (2009) Ralstonia Eutropha Strain H16 as Model Organism for PHA Metabolism and for Biotechnological Production of Technically Interesting Biopolymers. Journal of Molecular Microbiology and Biotechnology, 16, 91-108. http://dx.doi.org/10.1159/000142897

[99] Singh, M., Patel, S.K.S. and Kalia, V.C. (2009) Bacillus subtilis as Potential Producer for Polyhydroxyalkanoates. Microbial Cell Factories, 8, 38-48. http://dx.doi.org/10.1186/1475-2859-8-38

[100] Rojas-Rosas, O., Villafana-Rojas, J., Lopez-Dellamary, F.A., Nungaray-Arellano, J. and Gonzalez-Reynoso, O. (2007) Production and Characterization of Polyhydroxyalkanoates in Pseudomonas aeruginosa ATCC (9027) from Glucose, an Unrelated Carbon Source. Ca- 
nadian Journal of Microbiology, 53, 840-851. http://dx.doi.org/10.1139/W07-023

[101] Asada, Y., Miyake, M., Miyake, J., Kurane, R. and Tokiwa, Y. (1999) Photosynthetic Accumulation of Poly-(Hydroxybutyrate) by Cyanobacteria-The Metabolism and Potential for CO2 Recycling. International Journal of Biological Macromolecules, 25, 37-42. http://dx.doi.org/10.1016/S0141-8130(99)00013-6

[102] Schubert, P., Steinbuchel, A. and Schlegel, H.G. (1988) Cloning of the Alcaligenes eutrophus Genes for Synthesis of Poly-Beta-Hydroxybutyric Acid (PHB) and Synthesis of PHB in Escherichia coli. Journal of Bacteriology, 170, 5837-5847.

[103] Lee, S.Y., Choi, J.I. and Wong, H.H. (1999) Recent Advances in Polyhydroxyalkanoate Production by Bacterial Fermentation: Mini-Review. International Journal of Biological Macromolecules, 25, 31-36. http://dx.doi.org/10.1016/S0141-8130(99)00012-4

[104] Steinbüchel, A. and Valentin, H.E. (1995) Diversity of Bacterial Polyhydroxyalkanoic Acids. FEMS Microbiology Letters, 128, 219-228. http://dx.doi.org/10.1111/j.1574-6968.1995.tb07528.x

[105] Savenkova, L., Gercberga, Z., Nikolaeva, V., Dzene, A., Bibers, I. and Kalina, M. (2000) Mechanical Properties and Biodegradation Characteristics of PHB-Based Films. Process Biochemistry, 35, 537-579. http://dx.doi.org/10.1016/S0032-9592(99)00107-7

[106] Reis, K.C., Pereira, J., Smith, A.C., Carvalho, C.W.P., Wellner, N. and Yakimets, I. (2008) Characterization of Polyhydroxybutyrate-Hydroxyvalerate (PHB-HV)/Maize Starch Blend Films. Journal of Food Engineering, 89, 361-369. http://dx.doi.org/10.1016/j.jfoodeng.2008.04.022

[107] Philip, S., Keshavarz, T. and Roy, I. (2007) Polyhydroxyalkanoates: Biodegradable Polymers with a Range of Applications. Journal of Chemical Technology and Biotechnology, 2, 233 247. http://dx.doi.org/10.1002/jctb.1667

[108] Takahara, I., Saito, M., Inaba, M. and Murata, K. (2005) Dehydration of Ethanol into Ethylene over Solid Acid Catalysts. Catalysis Letters, 105, 249-252. http://dx.doi.org/10.1007/s10562-005-8698-1

[109] Hu, Y.C., Zhan, N.N., Dou, C., Huang, H., Han, Y.W., Yu, D.H. and Hu, Y. (2010) Selective Dehydration of Bio-Ethanol to Ethylene Catalyzed by Lanthanum-Phosphorous-Modified Hzsm-5, Influence of the Fusel. Biotechnology Journal, 5, 1186-1191.

http://dx.doi.org/10.1002/biot.201000139

[110] Phillips, A.L. (2008) Bioplastics Boom. American Scientist, 96, 109-110.

[111] Mathers, R.T. (2012) How Well Can Renewable Resources Mimic Commodity Monomers and Polymers? Journal of Polymer Science Part A: Polymer Chemistry, 50, 1-15. http://dx.doi.org/10.1002/pola.24939

[112] Yao, K. and Tang, C. (2013) Controlled Polymerization of Next-Generation Renewable Monomers and Beyond. Macromolecules, 46, 1689-1712. http://dx.doi.org/10.1021/ma3019574

[113] Kobayashi, H. and Fukuoka, A. (2013) Synthesis and Utilisation of Sugar Compounds Derived from Lignocellulosic Biomass. Green Chemistry, 15, 1740-1763. http://dx.doi.org/10.1039/c3gc00060e

[114] Fenouillot, F., Rousseau, A., Colomines, G., Saint-Loup, R. and Pascault, J.-P. (2010) Polymers from Renewable 1,4:3,6-Dianhydrohexitols (Isosorbide, Isomannide and Isoidide): A Review. Progress in Polymer Science, 35, 578-622. http://dx.doi.org/10.1016/j.progpolymsci.2009.10.001

[115] Wee, Y.J., Kim, J.N. and Ryu, H.W. (2006) Biotechnological Production of Lactic Acid and Its Recent Applications. Food Technology and Biotechnology, 44, 163-172. 
[116] Sauer, M., Porro, D., Mattanovich, D. and Branduardi, P. (2008) Microbial Production of Organic Acids: Expanding the Markets. Trends in Biotechnology, 26, 100-108.

http://dx.doi.org/10.1016/j.tibtech.2007.11.006

[117] Zhou, Y., Dominguez, J.M., Cao, N., Du, J and Tsao, G.T. (1999) Optimization of L-lactic Acid Production from Glucose by Rhizopus oryzae ATCC 52311. Applied Biochemistry and Biotechnology, 78, 401-407. http://dx.doi.org/10.1385/ABAB:78:1-3:401

[118] Zhou, S., Causey, T.B., Hasona, A., Shanmugam, K.T. and Ingram, L.O. (2003) Production of Optically Pure D-Lactic Acid in Mineral Salts Medium by Metabolically Engineered Escherichia coli W3110. Applied and Environmental Microbiology, 69, 399-407. http://dx.doi.org/10.1128/AEM.69.1.399-407.2003

[119] Mazumdar, S., Clomburg, J.M. and Gonzalez, R. (2010) Escherichia coli Strains Engineered for Homofermentative Production of D-Lactic Acid from Glycerol. Applied and Environmental Microbiology, 76, 4327-4336. http://dx.doi.org/10.1128/AEM.00664-10

[120] Jung, Y.K., Kim, T.Y., Park, S.J. and Lee, S.Y. (2010) Metabolic Engineering of Escherichia Coli for the Production of Polylactic Acid and Its Copolymers. Biotechnology and Bioengineering, 105, 161-171. http://dx.doi.org/10.1002/bit.22548

[121] Yang, T.H., Kim, T.W., Kang, H.O., Lee, S.H., Lee, E.J., Lim, S.C., Oh, S.O., Song, A.J., Park, S.J. and Lee, S.Y. (2010) Biosynthesis of Polylactic Acid and Its Copolymers Using Evolved Propionate CoA Transferase and PHA Synthase. Biotechnology and Bioengineering, 105, 150-160. http://dx.doi.org/10.1002/bit.22547

[122] Dorgan, J.R., Lehermeier, H. and Mang, M. (2000) Thermal and Rheological Properties of Commercial-Grade Poly(Lactic Acid)s. Journal of Polymers and the Environment, 8, 1-9. http://dx.doi.org/10.1023/A:1010185910301

[123] Nagasawa, N., Kaneda, A., Kanasawa, S., Yagi, T., Mitomo, H., Yoshii, F. and Tamada, M. (2005) Application of Poly(Lactic Acid) Modified by Radiation Crosslinking. Nuclear Instruments and Methods in Physic Research B, 236, 611-616. http://dx.doi.org/10.1016/j.nimb.2005.04.052

[124] Yang, F., Murugan, R., Wang, S. and Ramakrishna, S. (2005) Electrospinning of Nano/Micro Scale Poly(L-Lactic Acid) Aligned Fibers and Their Potential in Neural Tissue Engineering. Biomaterials, 26, 2603-2610. http://dx.doi.org/10.1016/j.biomaterials.2004.06.051

[125] Song, H. and Lee, S.Y. (2006) Production of Succinic Acid by Bacterial Fermentation. Enzyme and Microbial Technology, 39, 352-361. http://dx.doi.org/10.1016/j.enzmictec.2005.11.043

[126] Thakker, C., Martinez, I., San, K.Y. and Bennett, G.N. (2012) Succinate Production in Escherichia coli. Biotechnology Journal, 7, 213-224. http://dx.doi.org/10.1002/biot.201100061

[127] Lee, S.J., Lee, D.Y., Kim, T.Y., Kim, B.H. and Lee, S.Y. (2005) Metabolic Engineering of Escherichia coli for Enhanced Production of Succinic Acid, Based on Genome Comparison and in Silico Gene Knockout Simulation. Applied and Environmental Microbiology, 71, 7880-7887. http://dx.doi.org/10.1128/AEM.71.12.7880-7887.2005

[128] Qian, Z.G., Xia, X.X. and Lee, S.Y. (2009) Metabolic Engineering of Escherichia coli for the Production of Putrescine: A Four Carbon Diamine. Biotechnology and Bioengineering, 104, 651-662. http://dx.doi.org/10.1002/bit.22502

[129] Bechthold, I., Bretz, K., Kabasci, S., Kopitzky, R. and Springer, A. (2008) Succinic Acid: A New Platform Chemical for Biobased Polymers from Renewable Resources. Chemical Engineering and Technology, 31, 647-654. http://dx.doi.org/10.1002/ceat.200800063

[130] Xu, J. and Guo, B.H. (2010) Poly(Butylene Succinate) and Its Copolymers: Research, De- 
velopment and Industrialization. Biotechnology Journal, 5, 1149-1163. http://dx.doi.org/10.1002/biot.201000136

[131] Wang, X., Zou, J. and Li, L. (2007) Multiple Melting Behavior of Poly(Butylene Succinate). European Polymer Journal, 43, 3161-3170. http://dx.doi.org/10.1016/j.eurpolymj.2007.05.013

[132] Xu, Y., Xu, J., Gou, B. and Xie, X. (2007) Crystallization Kinetics and Morphology of Biodegradable Poly(Butylene Succinate-Co-Propylene Succinate)s. Journal of Polymer Science Part B: Polymer Physics, 45, 420-428. http://dx.doi.org/10.1002/polb.20877

[133] Jovanovic, D., Nikolic, M.S. and Djonlagic, J. (2004) Synthesis and Characterisation of Biodegradable Aliphatic Copolyesters with Hydrophilic Soft Segments. Journal of the Serbian Chemical Society, 69, 1013-1028. http://dx.doi.org/10.2298/JSC0412013J

[134] Pepic, D., Zagar, E., Zigon, M., Krzan, A., Kunaver, M. and Djonlagic, J. (2008) Synthesis and Characterization of Biodegradable Aliphatic Copolyesters with Poly(Ethylene Oxide) Soft Segments. European Polymer Journal, 44, 904-917. http://dx.doi.org/10.1016/j.eurpolymj.2007.11.035

[135] Ahn, B.D., Kim, S.H., Kim, Y.H. and Yang, J.S. (2001) Synthesis and Characterization of the Biodegradable Copolymers from Succinic Acid and Adipic Acid with 1,4-Butanediol. Journal of Applied Polymer Science, 82, 2808-2826. http://dx.doi.org/10.1002/app.2135

[136] Velmathi, S., Nagahata, R., Sujiyama, J. and Takeuchi, K. (2005) A Rapid Eco-Friendly Synthesis of Poly(Butylene Succinate) by a Direct Polyesterification under Microwave Irradiation. Macromolecular Rapid Communications, 26, 1163-1167. http://dx.doi.org/10.1002/marc.200500176

[137] Zhu, C.Y., Zhang, Z.G., Liu, Q.P., Wang, Z.P. and Jin, J. (2003) Synthesis and Biodegradation of Aliphatic Polyesters from Dicarboxylic Acids and Diols. Journal of Applied Polymer Science, 90, 982-990. http://dx.doi.org/10.1002/app.12722

[138] Bikiaris, D.N., Papageorgiou, G.Z. and Achilias, D.S. (2006) Synthesis and Comparative Biodegradability Studies of Three Poly(Alkylene Succinates). Polymer Degradation and Stability, 91, 31-43. http://dx.doi.org/10.1016/j.polymdegradstab.2005.04.030

[139] Kim, M.N., Kim, K.H., Jin, H.J., Park, J.K. and Yoon, J.S. (2001) Biodegradability of Ethyl and N-Octyl Branched Poly(Ethylene Adipate) and Poly(Butylene Succinate). European Polymer Journal, 37, 1843-1847. http://dx.doi.org/10.1016/S0014-3057(01)00003-9

[140] Jin, H.J., Lee, B.Y., Kim, M.N. and Yoon, J.S. (2000) Thermal and Mechanical Properties of Mandelic Acid-Copolymerized Poly(Butylene Succinate) and Poly(Ethylene Adipate). Journal of Polymer Science Part B: Polymer Physics, 38, 1504-1511. http://dx.doi.org/10.1002/(SICI)1099-0488(20000601)38:11<1504::AID-POLB100>3.0.CO;2-4

[141] Abe, H. and Dui, Y. (2004) Novel Biodegradable Copolymers with a Periodic Sequence Structure Derived from Succinate Butane-1,4-Diol, and Butane-1,4-Diamine. Macromolar Rapid Communications, 25, 1303-1308. http://dx.doi.org/10.1002/marc.200400154

[142] Jiang, X., Meng, X. and Xian, M. (2009) Biosynthetic Pathways for 3-Hydroxypropionic Acid Production. Applied Microbiology and Biotechnology, 82, 995-1003. http://dx.doi.org/10.1007/s00253-009-1898-7

[143] Gao, H.J., Wu, Q. and Chen, G.Q. (2002) Enhanced Production of D-(-)-3-Hydroxybutyric Acid by Recombinant Escherichia coli. FEMS Microbiology Letters, 213, 59-65. http://dx.doi.org/10.1016/s0378-1097(02)00788-7

[144] Tseng, H.C., Martin, C.H., Nielsen, D.R. and Prather, K.L. (2009) Metabolic Engineering of Escherichia coli for Enhanced Production of (R)- and (S)-3-Hydroxybutyrate. Applied and Environmental Microbiology, 75, 3137-3145. http://dx.doi.org/10.1128/AEM.02667-08 
[145] Tseng, H.C., Harwell, C.L., Martin, C.H. and Prather, K.L. (2010) Biosynthesis of Chiral 3-Hydroxyvalerate from Single Propionate-Unrelated Carbon Sources in Metabolically Engineered E. coli. Microbial Cell Factories, 9, 96-118. http://dx.doi.org/10.1186/1475-2859-9-96

[146] Nagarajan, V. and Nakamura, C. E. (1998) Production of 1,3-Propanediol from Glycerol by Recombinant Bacteria Expressing Recombinant Diol Dehydratase. US Patent No. 5821092.

[147] Nakamura, C.E. and Gatenby, A.A. (1998) Method for the Production of 1,3-Propanediol by Recombinant Microorganisms. US Patent No. 6013494.

[148] Kelsey, D.R. (1998) Copolyester Composition. US Patent No. 5705575.

[149] DuPont Performance Polymers (2013). http://www2.dupont.com/Plastics/en_US/assets/downloads/news/PP-EU-2013-09_The_Sci ence_Behind_ENGLISH.pdf

[150] Holladay, J.E., White, J.F., Bozell, J.J. and Johnson, D. (2007) Top Value-Added Chemicals from Biomass, Vol. II-Results of Screening for Potential Candidates from Biorefinery Lignin. U.S. Department of Energy, Washington DC. http://dx.doi.org/10.2172/921839

[151] Bozell, J.J. and Petersen, G.R. (2010) Technology Development for the Production of Biobased Products from Biorefinery Carbohydrates-The US Department of Energy's “Top 10" Revisited. Green Chemistry, 12, 539-554. http://dx.doi.org/10.1039/b922014c

[152] Marshall, A.L. and Alaimo, P.J. (2010) Useful Products from Complex Starting Materials: Common Chemicals from Biomass Feedstocks. Chemistry-A European Journal, 16, 49704980. http://dx.doi.org/10.1002/chem.200903028

[153] Belgacem, M.N. and Gandini, A. (2008) Monomers, Polymers and Composites from Renewable Resources. Elsevier, Amsterdam.

[154] Gandini, A. (2011) The Irruption of Polymers from Renewable Resources on the Scene of Macromolecular Science and Technology. Green Chemistry, 13, 1061-1083. http://dx.doi.org/10.1039/c0gc00789g

[155] Gandini, A. (2010) Furans as Offspring of Sugars and Polysaccharides and Progenitors of a Family of Remarkable Polymers: A Review of Recent Progress. Polymer Chemistry, 1, 245 251. http://dx.doi.org/10.1039/B9PY00233B

[156] Gandini, A., Silvestre, A.J.D., Neto, C.P. and Sousa, A.F. (2009) The Furan Counterpart of Poly(Ethylene Terephthalate): An Alternative Material Based on Renewable Resources. Journal of Polymer Science Part A: Polymer Chemistry, 47, 295-298. http://dx.doi.org/10.1002/pola.23130

[157] Gandini, A., Coelho, D., Gomes, M., Reis, B. and Silvestre, A. (2009) Materials from Renewable Resources Based on Furan Monomers and Furan Chemistry: Work in Progress. Journal of Materials Chemistry, 19, 8656-8664. http://dx.doi.org/10.1039/b909377j

[158] Gomes, M., Gandini, A., Silvestre, A.J.D. and Reis, B. (2011) Ring-Opening Synthesis of Polyethylene Furanoate (PEF) as a Renewable Resource-Based Substitute for Polyethylene Terephthalate (PET). Journal of Polymer Science Part A: Polymer Chemistry, 49, 37593768. http://dx.doi.org/10.1002/pola.24812

[159] Ma, J., Pang, Y., Wang, M., Xu, J., Ma, H. and Nie, X. (2012) The Copolymerization Reactivity of Diols with 2,5-Furandicarboxylic Acid for Furan-Based Copolyester Materials. Journal of Materials Chemistry, 22, 3457-3461. http://dx.doi.org/10.1039/c2jm15457a

[160] Sousa, A.F., Matos, M., Freire, C.S.R., Silvestre, A.J.D. and Coelho, J.F.J. (2013) New Copolyesters Derived from Terephthalic and 2,5-Furandicarboxylic Acids: A Step forward in the Development of Biobased Polyesters. Polymer, 54, 513-519. http://dx.doi.org/10.1016/j.polymer.2012.11.081 
[161] Pan, T., Deng, J., Xu, Q., Zuo, Y., Guo, Q.X. and Fu, Y. (2013) Catalytic Conversion of Furfural into a 2,5-Furandicarboxylic Acid-Based Polyester with Total Carbon Utilization. ChemSusChem, 6, 47-50. http://dx.doi.org/10.1002/cssc.201200652

[162] Papageorgiou, G.Z., Guigo, N., Tsanaktsis, V., Papageorgiou, D.G., Exarhopoulos, S., Sbirrazzuoli, N. and Bikiaris, D.N. (2015) On the Bio-Based Furanic Polyesters: Synthesis and Thermal Behavior Study of Poly(Octylene Furanoate) Using Fast and Temperature Modulated Scanning Calorimetry. European Polymer Journal, 68, 115-127. http://dx.doi.org/10.1016/j.eurpolymj.2015.04.011

[163] Wu, L., Mincheva, R., Xu, Y., Raquez, J.M. and Dubois, P. (2012) High Molecular Weight Poly(Butylene Succinate-Co-Butylenefurandicarboxylate) Copolyesters: From Catalyzed Polycondensation Reaction to Thermomechanical Properties. Biomacromolecules, 13, 2973-2981. http://dx.doi.org/10.1021/bm301044f

[164] Mialon, L., Pemba, A.G. and Miller, S.A. (2010) Biorenewable Polyethylene Terephthalate Mimics Derived from Lignin and Acetic Acid. Green Chemistry, 12, 1704-1706. http://dx.doi.org/10.1039/c0gc00150c

[165] Miller, S.A. and Mialon, L. (2013) Poly(Dihydroferulic Acid) a Biorenewable Polyethylene Terephthalate Mimic Derived from Lignin and Acetic Acid and Copolymers Thereof. US Patent No. 2013/0137847 A1.

[166] Mialon, L., Vanderhenst, R., Pemba, A.G. and Miller, S.A. (2011) Polyalkylenehydroxybenzoates (PAHBS): Biorenewable Aromatic/Aliphatic Polyesters from Lignin. Macromolar Rapid Communications, 32, 1386-1392. http://dx.doi.org/10.1002/marc.201100242

[167] Firdaus, M. and Meier, M.A.R. (2013) Renewable Co-Polymers Derived from Vanillin and Fatty Acid Derivatives. European Polymer Journal, 49, 156-166. http://dx.doi.org/10.1016/j.eurpolymj.2012.10.017

[168] Dong, W., Li, H., Chen, M., Ni, Z., Zhao, J., Yang, H. and Gijsman, P. (2011) Biodegradable Bio-Based Polyesters with Controllable Photo-Crosslinkability, Thermal and Hydrolytic Stability. Journal of Polymer Research, 18, 1239-1247. http://dx.doi.org/10.1007/s10965-010-9526-x

[169] Dong, W., Ren, J., Lin, L., Shi, D., Ni, Z. and Chen, M. (2012) Novel Photocrosslinkable and Biodegradable Polyester from Bio-Renewable Resource. Polymer Degradation and Stability, 97, 578-583. http://dx.doi.org/10.1016/j.polymdegradstab.2012.01.008

[170] Kuciel, S., Kuzniar, P. and Liber-Knec, A. (2012) Polyamides from Renewable Sources as Matrices of Short Fiber Reinforced Biocomposites. Polimery, 57, 627-634. http://dx.doi.org/10.14314/polimery.2012.627

[171] Matadi, R., Hablot, E., Wanga, K., Bahlouli, N., Ahzi, S. and Averous, L. (2011) High Strain Rate Behaviour of Renewable Biocomposites Based on Dimer Fatty Acid Polyamides and Cellulose Fibres. Composites Science and Technology, 71, 674-682. http://dx.doi.org/10.1016/j.compscitech.2011.01.010

[172] Hablot, E., Matadi, R., Ahzi, S. and Averous, L. (2010) Renewable Biocomposites of Dimer Fatty Acid-Based Polyamides with Cellulose Fibres: Thermal, Physical and Mechanical Properties. Composites Science and Technology, 70, 504-509. http://dx.doi.org/10.1016/j.compscitech.2009.12.001

[173] Ranganathan, S., Kumar, R. and Maniktala, V. (1984) On the Mechanism and Synthetic Applications of the Thermal and Alkaline Degradation of C-18 Castor Oil. Tetrahedron, 40, 1167-1178. http://dx.doi.org/10.1016/S0040-4020(01)99322-6

[174] Lu, W., Ness, J.E., Xie, W., Zhang, X., Minshull, J. and Gross, R.A. (2010) Biosynthesis of Monomers for Plastics from Renewable Oils. Journal of American Chemical Society, 132, 
15451-15455. http://dx.doi.org/10.1021/ja107707v

[175] Guillaume, L., Jouanneau, J. and Briffaudd, T. (2011) Polyamides, Composition Comprising such a Polyamide and their Uses. US Patent No. 20110189419 A1.

[176] Kind, S. and Wittmann, C. (2011) Bio-Based Production of the Platform Chemical 1,5Diaminopentane. Applied Microbiology and Biotechnology, 91, 1287-1296. http://dx.doi.org/10.1007/s00253-011-3457-2

[177] Qian, Z.G., Xia, X.X. and Lee, S.Y. (2011) Metabolic Engineering of Escherichia coli for the Production of Cadaverine: A Five Carbon Diamine. Biotechnology and Bioengineering, 108, 93-103. http://dx.doi.org/10.1002/bit.22918

[178] Yamano, N., Kawaski, N., Nakayama, A., Yamamoto, N. and Aiba, S. (2005) Mechanism and Characterization of Polyamide 4 Degradation by Pseudomonas sp. Journal of Polymers and the Environment, 16, 141-146. http://dx.doi.org/10.1007/s10924-008-0090-y

[179] Winkler, M., Steinbiß, M. and Meier, M.A.R. (2014) A More Sustainable Wohl-Ziegler Bromination: Versatile Derivatization of Unsaturated Fames and Synthesis of Renewable Polyamides. European Journal of Lipid Science and Technology, 116, 44-51. http://dx.doi.org/10.1002/ejlt.201300126

[180] Trefzer, A.C. and Turk, S.C.H.J. (2012) Method for Preparing Alfa-Ketopimelic Acid by $\mathrm{C}_{1}$-Elongation. WO Patent No. 2012/031910 A2.

[181] Raemakers-Franken, P.C., Nossin, P.M.M., Brandts, P.M., Wubbolts, M.G., Peeters, W.P.H., Ernste, S., Wildeman De, S.M.A. and Schuermann, M. (2009) Biochemical Synthesis of 6-Amino Caproic Acid. US Patent No. 2009/0137759 A1.

[182] Buijs, W., Wolkers, H.F.W., Guit, R.P.M. and Agterberg, F.P.W. (2001) Process to Prepare Caprolactam. US Patent No. 6.194.572 B1.

[183] Qi, W.W. Vannelli, T., Breinig, S., Ben-Bassat, A., Gatenby, A.A., Haynie, S.L. and Sariaslani, F.S. (2007) Functional Expression of Prokaryotic and Eukaryotic Genes in Escherichia coli for Conversion of Glucose to p-Hydroxystyrene. Metabolic Engineering, 9, 268-276. http://dx.doi.org/10.1016/j.ymben.2007.01.002

[184] McKenna, R. and Nielsen, D.R. (2011) Styrene Biosynthesis from Glucose by Engineered $E$. coli. Metabolic Engineering, 13, 544-554. http://dx.doi.org/10.1016/j.ymben.2011.06.005

[185] Li, H. and Huneault, M.A. (2011) Comparison of Sorbitol and Glycerol as Plasticizers for Thermoplastic Starch in TPS/PLA Blends. Journal of Applied Polymer Science, 119, 24392448. http://dx.doi.org/10.1002/app.32956

[186] Wilpiszewska, K. and Spychaj, T. (2011) Ionic Liquids: Media for Starch Dissolution, Plasticization and Modification. Carbohydrate Polymers, 86, 424-428. http://dx.doi.org/10.1016/j.carbpol.2011.06.001

[187] Liu, H. and Zhang J., (2011) Research Progress in Toughening Modification of Poly(Lactic Acid). Journal of Polymer Science Part B: Polymer Physics, 49, 1051-1083. http://dx.doi.org/10.1002/polb.22283

[188] Labrecque, L.V., Kumar, R.A., Davé, V., Gross, R.A. and McCarthy, S.P. (1997) Citrate Esters as Plasticizers for Poly(Lactic Acid). Journal of Applied Polymer Science, 6, 1507- 1513. http://dx.doi.org/10.1002/(SICI)1097-4628(19971121)66:8<1507::AID-APP11>3.0.CO;2-0

[189] Hassouna, F., Raquez, F., Addiego, J.M., Toniazzo, V., Dubois, P. and Ruch, D. (2012) New Development on Plasticized Poly(Lactide): Chemical Grafting of Citrate on PLA by Reactive Extrusion. European Polymer Journal, 48, 404-415.

http://dx.doi.org/10.1016/j.eurpolymj.2011.12.001 
[190] Jacobsen, S. and Fritz, H.G. (1999) Plasticizing Polylactide-The Effect of Different Plasticizers on the Mechanical Properties. Polymer Engineering Science, 39, 1303-1310. http://dx.doi.org/10.1002/pen.11517

[191] Jacobsen, S. and Fritz, H.G. (1996) Filling of Poly(Lactic Acid) with Native Starch. Polymer Engineering Science, 36, 2799-2804. http://dx.doi.org/10.1002/pen.10680

[192] Hassouna, F., Raquez, J.M., Addiego, F., Dubois, P., Toniazzo, V. and Ruch, D. (2011) New Approach on the Development of Plasticized Polylactide (PLA): Grafting of Poly(Ethylene Glycol) (PEG) via Reactive Extrusion. European Polymer Journal, 47, 2134-2344. http://dx.doi.org/10.1016/j.eurpolymj.2011.08.001

[193] Martin, O. and Avérous, L. (2001) Poly(Lactic Acid): Plasticization and Properties of Biodegradable Multiphase Systems. Polymer, 42, 6209-6219. http://dx.doi.org/10.1016/S0032-3861(01)00086-6

[194] Bibers, I., Tupureina, V., Dzene, A. and Kalnins, M. (1999) Improvement of the Deformative Characteristics of Poly-B-Hydroxybutyrate by Plasticization. Mechanics of Composite Materials, 35, 357-364. http://dx.doi.org/10.1007/BF02259726

[195] Ceccorulli, G., Pizzoli, M. and Scandola, M. (1992) Plasticization of Bacterial Poly(3-Hydroxybutyrate). Macromolecules, 25, 3304-3306. http://dx.doi.org/10.1021/ma00038a045

[196] Sudesh, K., Abe, H. and Doi, Y. (2000) Synthesis, Structure and Properties of Polyhydroxyalkanoates: Biological Polyesters. Progress in Polymer Science, 25, 1503-1555. http://dx.doi.org/10.1016/S0079-6700(00)00035-6

[197] Pellegrini, C. and Tomka, I. (1998) Starch Alkanoates as Models for Thermoplastic Polysaccharides. Macromolecular Symposia, 127, 31-35. http://dx.doi.org/10.1002/masy.19981270107

[198] Wang, H., Sun, X.Z. and Seib, P. (2002) Mechanical Properties of Poly(Lactic Acid) and Wheat Starch Blends with Methylenediphenyl Diisocyanate. Journal of Applied Polymer Science, 84, 1257-1262. http://dx.doi.org/10.1002/app.10457

[199] Zhang, J.F. and Sun, X.Z. (2004) Mechanical Properties of Poly(Lactic Acid)/Starch Composites Compatibilized by Maleic Anhydride. Biomacromolecules, 5, 1446-1451. http://dx.doi.org/10.1021/bm0400022

[200] Kim, S.H., Chin, I.J., Yoon, J.S., Kim, S.H. and Jung, J.S. (1998) Mechanical Properties of Biodegradable Blends of Poly(L-Lactic Acid) and Starch. Korea Polymer Journal, 6, 422427.

[201] Park, J.W., Lee, D.J., Yoo, E., Im, S.S., Kim, S.H. and Kim, Y.H. (1999) Biodegradable Polymer Blends of Poly(Lactic Acid) and Starch. Korea Polymer Journal, 7, 93-101.

[202] Park, J.W. and Im, S.S. (2000) Biodegradable Polymer Blends of Poly(L-Lactic Acid) and Gelatinized Starch. Polymer Engineering Science, 40, 2539-2550.

http://dx.doi.org/10.1002/pen.11384

[203] Koenig, M.F. and Huang, S.T. (1995) Biodegradable Blends and Composites of Polycaprolactone and Starch Derivatives. Polymer, 36, 1877-1882. http://dx.doi.org/10.1016/0032-3861(95)90934-T

[204] Averous, L., Moro, L., Dole, P. and Fringant, C. (2000) Properties of Thermoplastic Blends: Starch-Polycaprolactone. Polymer, 41, 4157-4167. http://dx.doi.org/10.1016/S0032-3861(99)00636-9

[205] Mani, R. and Bhattacharya, M. (2001) Properties of Injection Moulded Blends of Starch and Modified Biodegradable Polyesters. European Polymer Journal, 37, 515-526. http://dx.doi.org/10.1016/S0014-3057(00)00155-5 
[206] Bastioli, C., Cerutti, A., Guanella, I., Romano, G.C. and Tosin, M. (1995) Physical State and Biodegradation Behavior of Starch-Polycaprolactone Systems. Journal of Environmental Polymer Degradation, 3, 81-95. http://dx.doi.org/10.1007/BF02067484

[207] Mani, R., Tang, J. and Bhattacharya, M. (1998) Synthesis and Characterization of StarchGraft-Polycaprolactone as Compatibilizer for Starch/Polycaprolactone Blends. Macromolecular Rapid Communications, 19, 283-286. http://dx.doi.org/10.1002/(SICI)1521-3927(19980601)19:6<283::AID-MARC283>3.3.CO;2-3

[208] Choi, E.J., Kim, C.H. and Park, J.K. (1999) Structure-Property Relationship in PCL/Starch Blend Compatibilized with Starch-g-PCL Copolymer. Journal of Polymer Science Part B: Polymer Physics, 37, 2430-2438. http://dx.doi.org/10.1002/(SICI)1099-0488(19990901)37:17<2430::AID-POLB14>3.0.CO;2-4

[209] Avella, M., Errico, M.E., Rimedio, R. and Sadocco, P. (2001) Preparation of Biodegradable Polyesters/High Amylose Starch Composites by Reactive Blending and Their Characterization. Journal of Applied Polymer Science, 83, 1432-1442.

http://dx.doi.org/10.1002/app.2304

[210] Cai, H.Y., Yu, J. and Qiu, Z.B. (2012) Miscibility and Crystallization of Biodegradable Poly(3-Hydroxybutyrate-Co-3-Hydroxyhexanoate)/Poly(Vinyl Phenol) Blends. Polymer Engineering Science, 52, 233-241. http://dx.doi.org/10.1002/pen.22069

[211] Yang, J., Liu, M.K., Zhang, B., Chen, X.C., Fu, R.W. and Zhang, M.Q. (2011) Intrinsic Fluorescence Studies of Compatibility in Thermoplastic Phenol Formaldehyde Resin/Poly $(\varepsilon$ Caprolactone) Blends. Express Polymer Letters, 5, 698-707. http://dx.doi.org/10.3144/expresspolymlett.2011.68

[212] Furukawa, T., Sato, H., Murakami, R., Zhang, J.M., Noda, I., Ochiai, S. and Ozaki, Y. (2007) Comparison of Miscibility and Structure of Poly(3-Hydroxybutyrate-Co-3-Hydroxyhexanoate)/Poly(L-Lactic Acid) Blends with Those of Poly(3hydroxybutyrate)/Poly(L-Lactic Acid) Blends Studied by Wide Angle X-Ray Diffraction, Differential Scanning Calorimetry, and FTIR Microspectroscopy. Polymer, 48, 1749-1755.

http://dx.doi.org/10.1016/j.polymer.2007.01.020

[213] Wasantha, L.M., Gunaratne, K. and Shanks, R.A. (2008) Miscibility, Melting, and Crystallization Behavior of Poly(Hydroxybutyrate) and Poly(D,L-Lactic Acid) Blends. Polymer Engineering \& Science, 48, 1683-1692. http://dx.doi.org/10.1002/pen.21051

[214] Park, J.W. and Im, S.S. (2002) Phase Behavior and Morphology in Blends of Poly(L-Lactic Acid) and Poly(Butylene Succinate). Journal of Applied Polymer Science, 86, 647-655. http://dx.doi.org/10.1002/app.10923

[215] Hinuber, C., Hausler, L., Vogel, R., Brunig, H., Heinrich, G. and Werner, C. (2011) Hollow Fibers Made from a Poly(3-Hydroxybutyrate)/Poly- $\varepsilon$-Caprolactone Blend. Express Polymer Letters, 5, 643-652. http://dx.doi.org/10.3144/expresspolymlett.2011.62

[216] Sungsanit, K., Kao, N. and Bhattacharaya, S.N. (2011) Properties of Linear Poly(Lactic Acid)/Polyethylene Glycol Blends. Polymer Engineering \& Science, 52, 108-116. http://dx.doi.org/10.1002/pen.22052

[217] Lovera, D., Marquez, L., Balsamo, V., Taddei, A., Castelli, C. and Muller, A.J. (2007) Crystallization, Morphology, and Enzymatic Degradation of Polyhydroxybutyrate/Polycaprolactone (PHB/PCL) Blends. Macromolecular Chemistry and Physics, 208, 924-937. http://dx.doi.org/10.1002/macp.200700011

[218] Suttiwijitpukdee, N., Sato, H., Unger, M. and Ozaki, Y. (2012) Effects of Hydrogen Bond Intermolecular Interactions on the Crystal Spherulite of Poly(3-Hydroxybutyrate) and Cellulose Acetate Butyrate Blends: Studied by FT-IR and FT-NIR Imaging Spectroscopy. Macromolecules, 45, 2738-2248. http://dx.doi.org/10.1021/ma201598s 
[219] Zhang, K.Y., Ran, X.H., Wang, X.M., Han, C.Y., Han, L.J., Wen, X., Zhuang, Y.G. and Dong, L.S. (2011) Improvement in Toughness and Crystallization of Poly(L-Lactic Acid) by Melt Blending with Poly(Epichlorohydrin-Co-Ethylene Oxide). Polymer Engineering \& Science, 51, 2370-2380. http://dx.doi.org/10.1002/pen.22009

[220] Jiao, J., Wang, S.J., Xiao, M., Xu, M. and Meng, Y.Z. (2007) Processability, Property, and Morphology of Biodegradable Blends of Poly(Propylene Carbonate) and Poly(Ethylene-CoVinyl Alcohol). Polymer Engineering \& Science, 47, 174-180. http://dx.doi.org/10.1002/pen.20694

[221] Cao, Y.X., Du, F.G., Wang, X.L. and Meng, Y.Z. (2006) New Biodegradable Blends from Aliphatic Polycarbonate and Poly(Vinyl Alcohol). Polymer Composites, 14, 577-584.

[222] Silva, S.S., Goodfellow, B.J., Benesch, J., Rocha, J., Mano, J.F. and Reis, R.L. (2007) Morphology and Miscibility of Chitosan/Soy Protein Blended Membranes. Carbohydrate Polymers, 70, 25-31. http://dx.doi.org/10.1016/j.carbpol.2007.02.023

[223] Li, L.H., Ding, S. and Zhou, C.R. (2004) Preparation and Degradation of PLA/Chitosan Composite Materials. Journal of Applied Polymer Science, 91, 274-277. http://dx.doi.org/10.1002/app.12954

[224] Coffin, D.R. and Fishman, M.L. (1997) Films fabricated from Mixtures of Pectin and Poly (Vinyl Alcohol). U.S. Patent No. 5,646,206.

[225] Fishman, M.L., Coffin, D.R., Onwulata, C.I. and Willett, J.L. (2006) Two Stage Extrusion of Plasticized Pectin/Poly(Vinyl Alcohol) Blends. Carbohydrate Polymers, 65, 421-429. http://dx.doi.org/10.1016/j.carbpol.2006.01.032

[226] Nishio, Y. and Manley, R.St.J. (1988) Cellulose/Poly(Vinyl Alcohol) Blends Prepared from Solution in N,N-Dimethylacetamide Lithium Chloride. Macromolecules, 21, 1270-1277. http://dx.doi.org/10.1021/ma00183a016

[227] Masson, J.F. and Manley, R.St.J. (1992) Solid-State NMR of Some Cellulose/Synthetic Polymer Blends. Macromolecules, 25, 589-592. http://dx.doi.org/10.1021/ma00028a016

[228] Kim, B.S., Baez, C.E. and Atala, A. (2000) Biomaterials for Tissue Engineering. World Journal of Urology, 18, 2-9. http://dx.doi.org/10.1007/s003450050002

[229] Sahoo, S., Sasmal, A., Sahoo, D. and Nayak, P. (2010) Synthesis and Characterization of Chitosan-Polycaprolactone Blended with Organoclay for Control Release of Doxycycline. Journal of Applied Polymer Science, 118, 3167-3175. http://dx.doi.org/10.1002/app.32474

[230] Liu, X., Lin, T., Gao, Y., Xu, Z.G., Huang, C., Yao, G., Jiang, L.L., Tang, Y.W. and Wang, X.G. (2012) Antimicrobial Electrospun Nanofibers of Cellulose Acetate and Polyester Urethane Composite for Wound Dressing. Journal of Biomedical Materials Research, 100B, 1556-1565. http://dx.doi.org/10.1002/jbm.b.32724

[231] Mano, J.F., Silva, G.A., Azevedo, H.S., Malafaya, P.B., Sousa, R.A., Silva, S.S., Boesel, L.F., Oliveira, J.M., Santos, T.C., Marques, A.P., Neves, N.M. and Reis, R.L. (2007) Natural Origin Biodegradable Systems in Tissue Engineering And Regenerative Medicine: Present Status and Some Moving Trends. Journal of the Royal Society Interface, 4, 999-1030. http://dx.doi.org/10.1098/rsif.2007.0220

[232] Wei, G.B. and Ma P.X., (2009) Partially Nanofibrous Architecture of 3D Tissue Engineering Scaffolds. Biomaterials, 30, 6426-6434. http://dx.doi.org/10.1016/j.biomaterials.2009.08.012

[233] Ginty, P.J., Barry, J.J.A., White, L.J., Howdle, S.M. and Shakesheff, K.M. (2008) Controlling Protein Release from Scaffolds Using Polymer Blends and Composites. European Journal of Pharmaceutics Biopharmaceutics, 68, 82-89. http://dx.doi.org/10.1016/j.ejpb.2007.05.023

[234] Tiyaboonchai, W., Chomchalao, P., Pongcharoen, S., Sutheerawattananonda, M. and Sob- 
hon, P. (2011) Preparation and Characterization of Blended Bombyx Mori Silk Fibroin Scaffolds. Fibers and Polymers, 12, 324-333. http://dx.doi.org/10.1007/s12221-011-0324-9

[235] Rezwan, K., Chen, Q.Z., Blaker, J.J. and Boccaccini, A.R. (2006) Biodegradable and Bioactive Porous Polymer/Inorganic Composite Scaffolds for Bone Tissue Engineering. Biomaterials, 27, 3413-3431. http://dx.doi.org/10.1016/j.biomaterials.2006.01.039

[236] Armentano, I., Dottori, M., Fortunati, E., Mattioli, S. and Kenny, J.M. (2010) Biodegradable Polymer Matrix Nanocomposites for Tissue Engineering: A Review. Polymer Degradation and Stability, 95, 2126-2146. http://dx.doi.org/10.1016/j.polymdegradstab.2010.06.007

[237] Lieleg, O. and Ribbeck, K. (2011) Biological Hydrogels as Selective Diffusion Barriers. Trends in Cell Biology, 21, 543-551. http://dx.doi.org/10.1016/j.tcb.2011.06.002

[238] Van Vlierberghe, S., Dubruel, P. and Schacht, E. (2011) Biopolymer-Based Hydrogels as Scaffolds for Tissue Engineering Applications: A Review. Biomacromolecules, 12, 1387 1408. http://dx.doi.org/10.1021/bm200083n

[239] Oh, J.K., Lee, D.I. and Park, J.M. (2009) Biopolymer-Based Microgels/Nanogels for Drug Delivery Applications. Progress in Polymer Science, 34, 1261-1282. http://dx.doi.org/10.1016/j.progpolymsci.2009.08.001

[240] Mallika, S.K. (2006) Imaging Viscoelasticity in Hydropolymers and Breast Tissue Ultrasound. Ph.D. Dissertation, University of California, Davis.

[241] Park, H., Li, X., Jin, C., Park, C., Cho, W. and Ha, C. (2002) Preparation and Properties of Biodegradable Thermoplastic Starch/Clay Hybrids. Macromolecular Materials and Engineering, 287, 553-558. http://dx.doi.org/10.1002/1439-2054(20020801)287:8<553::AID-MAME553>3.0.CO;2-3

[242] Park, H., W., Lee, C. Park, Cho, W. and Ha, C. (2003) Environmentally Friendly Polymer Hybrids. Part 1 Mechanical, Thermal and Barrier Properties of Thermoplastic Starch/Clay Nanocomposites. Journal of Materials Science, 38, 909-915. http://dx.doi.org/10.1023/A:1022308705231

[243] Wilhelm, H.M., Sierakowski, M.R., Souza, G.P. and Wypych, F. (2003) Starch Films Reinforced with Mineral Clay. Carbohydrate Polymers, 52, 101-110. http://dx.doi.org/10.1016/S0144-8617(02)00239-4

[244] Huang, M., Yu, J. and Ma, X. (2005) High Mechanical Performance MMT-Urea and Formamide-Plasticized Thermoplastic Cornstarch Biodegradable Nanocomposites. Carbohydrate Polymers, 62, 1-7.

[245] Pandey, J.K. and Sing, R.P. (2005) Green Nanocomposites from Renewable Resources: Effect of Plasticizer on the Structure and Material Properties of Clay-Filled Starch. Starch, 57, 8-15. http://dx.doi.org/10.1002/star.200400313

[246] Chiou, B.S., Wood, D., Yee, E., Imam, S.H., Glenn, G.M. and Orts, W.J. (2007) Extruded Starch-Nanoclay Nanocomposites: Effects of Glycerol and Nanoclay Concentration. Polymer Engineering Science, 47, 1898-1904. http://dx.doi.org/10.1002/pen.20903

[247] McGlashan, S.A. and Halley, P.J. (2003) Preparation and Characterization of Biodegradable Starch-Based Nanocomposite Materials. Polymer International, 52, 1767-1773. http://dx.doi.org/10.1002/pi.1287

[248] Kalambur, S. and Rizvi, S.S.H. (2005) Biodegradable and Functionally Superior Starch-Polyester Nanocomposites from Reactive Extrusion. Journal of Applied Polymer Science, 96, 1072-1082. http://dx.doi.org/10.1002/app.21504

[249] Park, H., Misra, M., Drzal, L.T. and Mohanty, A.K. (2004) Green Nanocomposites from Cellulose Acetate Bioplastic and Clay: Effect of Eco-Friendly Triethyl Citrate Plasticizer. Biomacromolecules. 5, 2281-2288. http://dx.doi.org/10.1021/bm049690f 
[250] Oksman, K., Mathew, A.P., Bondeson, D. and Kvien, I. (2006) Manufacturing Process of Cellulose Whiskers/Polylactic Acid Nanocomposites. Composites Science and Technology, 66, 2776-2784. http://dx.doi.org/10.1016/j.compscitech.2006.03.002

[251] Bondeson, D. and Oksman, K. (2007) Polylactic Acid/Cellulose Whisker Nanocomposites Modified by Polyvinyl Alcohol. Composites: Part A, 38, 2486-2492. http://dx.doi.org/10.1016/j.compositesa.2007.08.001

[252] de Menezes, A.J., Siqueira, G., Curvelo, A.A.S. and Dufresne, A. (2009) Extrusion and Characterization of Functionalized Cellulose Whiskers Reinforced Polyethylene Nanocomposites. Polymer, 50, 4552-4563. http://dx.doi.org/10.1016/j.polymer.2009.07.038

[253] Mancera Garcia, K.M., Meimaroglou, D., Hoppe, S., Pla, F. and Escobar-Barrios, V.A. (2015) Design and Process Modeling for the Manufacture by Extrusion of Recycled Polyethylene Terephtalate and Low Density Polyethylene Nanocomposites Reinforced with Cellulose Nanocrystals. Proceedings of the 10 th European Congress of Chemical Engineering. Nice, 27 September-1 October 2015, 655.

[254] Bandyopadhyay, S., Chen, R. and Giannelis, E.P. (1999) Biodegradable Organic Inorganic Hybrids Based on Poly(L-Lactic Acid). Polymeric Materials. Science and Engineering, 81, $159-160$.

[255] Maiti, P., Yamada, K., Okamoto, M., Ueda, K. and Okamoto, K. (2002) New Polylactide/ Layered Silicate Nanocomposites Role of Organoclay. Chemistry of Materials, 14, 46544661. http://dx.doi.org/10.1021/cm020391b

[256] Cabedo, L., Feijoo, J.L., Villanueva, M.P., Lagaron, J.M. and Gimenez, E. (2006) Optimization of Biodegradable Nanocomposites Based on PLA/PCL Blends for Food Packaging Applications. Macromolecular Symposia, 233, 191-197.

http://dx.doi.org/10.1002/masy.200690017

[257] Rebouillat, S. (2011) The Deformation of Saturated Soft Porous Materials: 1-Addressing the Determination of the Activation Energy for a Global Effective Transfer of Fluid through the Contact Zones during Multimode Shear/Compression. Chemical Engineering Science, 66, 5891-5898. http://dx.doi.org/10.1016/j.ces.2011.08.008

[258] Rebouillat, S., Peng, J.C.M., Donnet, J.-B. and Ryu, S.-K. (1998) In: Donnet, J.-B., Wang, T.K., Rebouillat, S., Peng, J.C.M., Eds., Carbon Fibers, 3rd Edition, Marcel Dekker, New York, 463-542.

Submit or recommend next manuscript to SCIRP and we will provide best service for you:

Accepting pre-submission inquiries through Email, Facebook, LinkedIn, Twitter, etc.

A wide selection of journals (inclusive of 9 subjects, more than 200 journals)

Providing 24-hour high-quality service

User-friendly online submission system

Fair and swift peer-review system

Efficient typesetting and proofreading procedure

Display of the result of downloads and visits, as well as the number of cited articles

Maximum dissemination of your research work

Submit your manuscript at: http://papersubmission.scirp.org/

Or contact jbnb@scirp.org 